KaTARZYNA KabACiŃSKA-ŁUCZAK

Uniwersytet im. Adama Mickiewicza

w Poznaniu

MONIKA NAWROT-BOROWSKA

Uniwersytet Kazimierza Wielkiego

$w$ Bydgoszczy

\title{
WYMARZONY PREZENT POD CHOINKE. O ZABAWKACH ŚWIĄTECZNYCH W LITERATURZE I CZASOPISMACH ADRESOWANYCH DO DZIECI II POŁOWY XIX I POCZĄTKU XX WIEKU
}

\begin{abstract}
AвSTRACT. Kabacińska-Łuczak Katarzyna, Nawrot-Borowska Monika, Wymarzony prezent pod choinkę. O zabawkach świątecznych w literaturze i czasopismach adresowanych do dzieci II połowy XIX i początku XX wieku [A Dream Christmas Gift. On Christimas Toys in Children's Literature and Magazines of the 2nd Half of the 19th c. and the Early 20th c.]. Studia Edukacyjne nr 49, 2018, Poznań 2018, pp. 77-105 Adam Mickiewicz University Press. ISSN 1233-6688. DOI: 10.14746/se.2018.49.6

Timeless attributes of children's games, i.e. toys, have been made the subject of research. The authors focus on the toys received by children from Polish families during Christmas. The aim of these analyses is therefore to characterise Christmas children's toys presented in two types of sources intentionally addressed to children: children's literature and press. The research covers the second half of the 19th century and the beginning of the following century. The article in its subject matter refers to the Authors' earlier research on Christmas toys and is in line with the ever developing trend of research on toys from the historical and pedagogical perspective.
\end{abstract}

Key words: children's toy, Christmas, literature

\section{Wprowadzenie}

Zabawki dziecięce stanowią ważny element kultury.

Właśnie zabawki - zdaniem Jana Bujaka - jak żadne inne przedmioty, przedstawiają pełny obraz wycinka rzeczywistości tej epoki, w której powstały. Są wiernym odbiciem kultury materialnej, duchowej i społecznej ${ }^{1}$.

${ }^{1}$ J. Bujak, B. Pilichowska, Zabawki, potrzeby badawcze, problemy teoretyczne, propozycje muzeologiczne, Studia i Materiały 1986, z. 1, s. 13. 
Należy również podkreślić, że zabawki i zabawy z ich wykorzystaniem stały się odbiciem oczekiwań społecznych danej epoki wobec dzieci oraz głoszonych poglądów pedagogicznych. Pewien tradycjonalizm zabawek w II połowie XIX i początku XX wieku wynikał zarówno z niezmiennych funkcji przedmiotów zabawy: ludycznej, edukacyjnej oraz przygotowawczej czy socjalizacyjnej, na które wpływały poglądy głoszone przez myślicieli, moralistów, teoretyków wychowania, pedagogów, psychologów oraz modelu wychowania dominującego w poszczególnych warstwach społecznych. Ów wzór sposobu życia rodziców miał niewątpliwy wpływ na proces wychowania, którego istotnym elementem były zabawki. To właśnie one miały bawić, wychowywać, socjalizować i przygotowywać do pełnienia odpowiednich ról w społeczeństwie.

Świat zabawy jest dla dziecka światem totalnym, podobnie jak w świadomości człowieka religijnego cała rzeczywistość odsłania tajemnicę boskości i jest nakierowanym ku sacrum doświadczeniem transcendencji. Kosmos zabawy jest bezkresny, obejmuje wszelkie dostępne dziecku przestrzenie rzeczywiste i nierzeczywiste, wszelkie obszary jego aktywności².

Zabawka w ręku dziecka staje się więc nie tylko rekwizytem zabawy, ale przede wszystkim przenosi je $\mathrm{w}$ "drugą rzeczywistość" ${ }^{3}$, stanowi jej immanentną cechę, jest także pełnoprawnym bohaterem zabawy. Wydaje się, że zabawka, będąc najbardziej oczekiwanym prezentem świątecznym, staje się doświadczeniem sacrum. Klimat świąt Bożego Narodzenia - czasu odświętnego, pełnego cudów, wpływa także na dziecko oczekujące z jednej strony uczestnictwa w obchodach i zwyczajach świątecznych, z drugiej - wejścia $\mathrm{w}$ świat sacrum zabawy z otrzymanym świątecznym prezentem.

Czas świąt Bożego Narodzenia był - i jest nadal - okresem, w którym wybór prezentu i jego ofiarowanie stają się bardzo ważne - szczególnie dla dzieci. Otrzymywały one prezenty w nie tylko w Wigilię, ale także już wcześniej - z okazji Świętego Mikołaja 6 grudnia, w sam dzień Bożego Narodzenia lub na tak zwaną kolędę, czyli na Nowy Rok, a także 6 stycznia podczas Trzech Królił . Prezenty, w zależności od regionu, przynosił Święty Mikołaj, Gwiazdor, Aniołek, Jezusek, Gwiazdka lub dawali rodzice, krewni, układając je pod choinką .

${ }^{2}$ G. Leszczyński, Kulturowy obraz dziecka i dzieciństwa w literaturze drugiej połowy XIX i w XX wieku, Warszawa 2006, s. 156-157.

${ }^{3}$ Określenie Wincentego Okonia; W. Okoń, Zabawa a rzeczywistość, Warszawa 1987.

${ }^{4}$ Por. K. Kabacińska-Łuczak, M. Nawrot-Borowska, Dziecięce zabawki świąteczne w świetle wybranych źródet ikonograficznych z II połowy XIX i początku XX wieku, Studia Edukacyjne 2017, 46.

${ }^{5}$ Por. szerzej M. Nawrot-Borowska, K. Kabacińska-Łuczak, Co podarować dziecku na Gwiazdkę? Porady pedagogiczne i oferty reklamowe dla kupujących zabawki z II połowy XIX i poczatku XX wieku, [w:] Dom-codzienność i święto. Ceremonie i tradycje rodzinne. Studia historyczno-antropologiczne, red. B. Popiołek, M. Gadocha, A. Chłosta-Sikorska, Kraków 2018 oraz K. Kabacińska-Łuczak, 


\section{Cel, źródła i ustalenia terminologiczne}

Celem niniejszych rozważań jest charakterystyka świątecznych zabawek dziecięcych, przedstawionych w dwóch typach źródeł z II połowy XIX i początku XX wieku, intencjonalnie kierowanych do dzieci: literaturze i prasie dziecięcej. Artykuł w swojej tematyce nawiązuje do wcześniejszych rozważań nad zabawkami świątecznymi ${ }^{6}$ i wpisuje się w coraz lepiej rozwijający się nurt badań nad zabawkami z perspektywy historyczno-pedagogicznej. Wykorzystane w pracy źródła - literatura oraz czasopisma adresowane do dzieci - stanowią specyficzną grupę materiałów badawczych. Ich swoistą cechą jest cel oraz sposób przekazu. Teksty pisane do młodego odbiorcy z II połowy XIX i początku XX wieku są nasycone dydaktyzmem, moralizatorstwem, prostą - pod względem językowym i konstrukcji - fabułą. Ich podstawową funkcją jest wychowywaćs. Ów dydaktyzm - zwany także dydaktyzmem retorycznym, nachalnym - przez prawie cały wiek XIX oparty był na zasadach nakazów lub zakazów, na pouczeniach lub wyidealizowanych wzorcach ${ }^{9}$. Bohaterowie tekstów mieli prostą konstrukcję psychologiczną i wyrażali ówcześnie propagowane wzory wychowania, wynikające z sytuacji społeczno-politycz-

M. Nawrot-Borowska, Dziecięce zabawki świateczne w świetle wybranych źródet ikonograficznych z II potowy XIX i poczatku XX wieku.

${ }^{6}$ Tamże.

7 Por. wybrane artykuły: D. Żołądź-Strzelczyk, "A cacek też dużo było”. Zabawki dziecięce na ziemiach polskich w średniowieczu i epoce nowożytnej, Kwartalnik Historyczny, 2013, 1, taże Rola zabawek w przygotowaniu do petnienia ról społecznych kobiecych i męskich w epoce nowożytnej, [w:] Kobieta i mężczyzna jedna przestrzeń - dwa światy, red. B. Popiołek, A. Chłosta-Sikorska, M. Gadocha, Warszawa 2015; K. Kabacińska, Zabawy i zabawki dziecięce w świetle polskiej nowelistyki pozytywistycznej, Zabawy i Zabawki, 2008, 1-4, taże Od grzechotki do .... - stów kilka o zabawkach dziecięcych, Studia Edukacyjne, 2010, 11; M. Nawrot-Borowska, Zabawy i zabawki dziecięce w drugiej potowie XIX i na początku XX wieku - wybrane problemy z wykorzystaniem grafik $z$ epoki, Biuletyn Historii Wychowania, 2013, 30, taże Obrazki z dziejów lalki, [w:] Z badań nad tradycja polskiej pedagogiki, t. 2: Księga jubileuszowa dedykowana Profesor Danucie Koźmian, red. nauk. E. Magiera, J. Król, Szczecin 2016; wybrane pozycje książkowe: K. Kabacińska, Zabawy i zabawki dziecięce w osiemnastowiecznej Polsce, Poznań 2007; Dawne zabawy dziecięce, red. D. Żołądź-Strzelczyk, K. Kabacińska, Kielce - Warszawa 2008; Dawne i wspótczesne zabawki dziecięce, red. D. Żołądź-Strzelczyk, K. Kabacińska, Poznań 2010; Zabawka - przedmiot ludyczny i obiekt kolekcjonerski, red. K. Kabacińska-Łuczak, D. Żołądź-Strzelczyk, Poznań 2016; D. ŻołądźStrzelczyk, I. Gomułka, K. Kabacińska-Łuczak, M. Nawrot-Borowska, Dzieje zabawek dziecięcych na ziemiach polskich do początku XX wieku, Wrocław 2016 - tutaj szczegółowa bibliografia dotycząca problematyki zabawek dziecięcych s. 437-457.

${ }^{8}$ Dostrzegalne zmiany w konstrukcji, języku i tematyce polskich tekstów adresowanych do dzieci następują w utworach Jana Brzechwy, Juliana Tuwima.

${ }^{9}$ Dzięki przemianom w polskiej literaturze adresowanej do dzieci, które zapoczątkowane zostały przez wprowadzenie do fabuły fantastyki (M. Konopnicka „O krasnoludkach i sierotce Marysi”) i przygody (H. Sienkiewicz „W pustyni i w puszczy”), można dostrzec zmianę punktu ciężkości w tekstach literatury dla dzieci - z funkcji dydaktycznej ku estetycznej; por. m.in. Z. Adamczykowa, Literatura dla dzieci. Funkcje, kategorie, gatunki, Warszawa 2001, s. 25-50. 
nej oraz trendów literackich (pozytywistyczna literatura tendencyjna). Istotne zmiany w literaturze dziecięcej można dostrzec w pierwszym dziesięcioleciu XX wieku. Dotyczą one przede wszystkim konstrukcji bohatera dziecięcego, zmiany jego statusu społecznego, wprowadzenia (pod wpływem modernizmu) fantastyki baśniowej, a także zwrócenia uwagi na szatę graficzną wydawanych dzieł. Owe przeobrażenia wynikają z faktu, że „Dziecko stało się w tym okresie tematem »modnym «, zaczęły powstawać subtelne studia psychologiczne, twórcy zaczęli interesować się »duszą dziecka «"10.

Czasopisma dla dzieci ${ }^{11}$, sięgające swoich początków roku 1824 („,Rozrywki dla Dzieci” redagowane przez Klementynę z Tańskich Hoffmanową), w latach 60. i 70. XIX wieku przeżywają rozwój, a na rynku wydawniczym pojawiają się między innymi „Przyjaciel Dzieci”, „Promyk”, „Wieczory Rodzinne". Jednak były to projekty krótkotrwałe. Najdłużej działającym periodykiem był „Mały Światek” (1887-1914). W czasopismach tych, podobnie jak w literaturze dla dzieci, dominowały pozytywistyczne tendencje wychowawcze. Pewne zmiany można dostrzec $w$ czasopismach z początku XX wieku, jak między innymi „Moje Pisemko”, ,Promyk”, ,Z bliska i z daleka”. W czasopismach tych zaczęto publikować teksty znanych pedagogów, działaczy oświatowych, literatów, między innymi Anieli Szycówny, Marii Buyno-Arctowej, Heleny Radlińskiej, Janusza Korczaka, Janiny Porazińskiej, Stefanii Sempołowskiej, zwrócono uwagę na szatę graficzną, wprowadzono nowe tendencje, na przykład „motyw przyjaźni i braterstwa między dziećmi wszystkich warstw i narodów $(. . .)^{\prime \prime 12}$ i nowe tematy walki o równość wszystkich klas, o prawa kobiet, nawoływanie do tolerancji religijnej i tym podobne ${ }^{13}$. Zwykle - w zależności od częstotliwości ukazywania się danego czasopisma - numer bądź numery grudniowe zawierały teksty poświęcone zbliżającym się świętom Bożego Narodzenia. Opisywano tradycje i zwyczaje świąteczne, zarówno religijne, jak i rodzinne, publikowano historyjki, powiastki, obrazki literackie, opowiadania, wierszyki, których tłem były przygotowania do świąt lub święta. W pismach ilustrowanych dołączano grafiki, na których prezentowano sceny religijne i rodzinne związane z Bożym Narodzeniem, podawano

${ }^{10}$ K. Kuliczkowska, Literatura dla dzieci i młodzieży w latach 1864-1918, Warszawa 1975, s. 114.

11 Prasa dziecięca - „czasopisma przeznaczone dla dzieci, przeważnie ilustrowane (...) zróżnicowane i przystosowane do poziomu umysłowego poszczególnych faz rozwojowych młodego czytelnika", [w:] Encyklopedia wiedzy o prasie, red. J. Maślanka, Wrocław - Warszawa - Kraków - Gdańsk 1976, s. 171; zob. też np.: A. Przecławska, Czasopisma dziecięce i młodzieżowe, [w:] Encyklopedia pedagogiczna, red. W. Pomykało, Warszawa 1997, s. 77-78; J. Papuzińska, Wychowawcza rola prasy dziecięcej, Warszawa 1972; S. Grabowski, Na przyszły pożytek. Z dziejów polskiej prasy dla dzieci 1824-1939, Pułtusk 2001; Stare i nowe. Czasopisma dla dzieci i młodzieży, red. B. Olszewska, E. Łucka-Zając, Opole 2013.

12 Tamże, s. 125.

13 Tamże, s. 127. 
sposoby wykonania i wzory zabawek choinkowych. Wprowadzano małych czytelników w radosny nastrój oczekiwania na ten piękny czas roku, nie zapominając oczywiście o fakcie najbardziej oczekiwanym przez najmłodszych - podarkach, jakimi były zabawki.

Dziateczki, za trzy tygodnie Gwiazdka! Ach, co to za radosna dla Was nowina! O tak, to najradośniejsza nowina dla was i całego świata, która nam przypomina przyjście Pana Jezusa na ziemię. Cieszy się cały świat i wy się cieszycie, bo boskie dzieciąteczko was i w tym roku darami swymi hojnie obsypie, przyniesie wam oto to, czego sobie życzycie ${ }^{14}$.

Z punktu widzenia historyka wychowania teksty adresowane do dzieci są cennym źródłem do badań nad codziennym światem dziecięcym, którego istotnym elementem są zabawki i zabawy dziecięce. Należy postawić pytanie: czym różnią się zabawki ukazane w tekstach adresowanych do dzieci od zabawek występujących w innych źródłach? Wydaje się, że istotne są dwie kwestie. Pierwsza, dotyczy ich funkcji. Zabawki pełnią ich kilka: ludyczną (zabawową) - „Pierwszym, koniecznym warunkiem każdej zabawki jest to, aby ona dziecię rzeczywiście bawiła"15, rozwojową/edukacyjną, na którą zwrócono uwagę w piśmiennictwie polskim w XVIII wieku ${ }^{16}$, a także wychowawczą (socjalizacyjną/ przygotowawczą), o której Zofia Seidlerowa pisała:

Osoby, które bliżej żyją ze światem dziecięcym, powinny zabawki wybierać z punktu widzenia pedagogiki, a nawet i sztuki, albowiem zabawka, zwłaszcza w pierwszych latach rozwoju dziecka, jest najważniejszym z pomocniczych środków wychowania ${ }^{17}$.

Na podstawie analizy tekstów intencjonalnie kierowanych do dzieci można dostrzec wybijającą się na plan pierwszy funkcję przygotowawczą/wychowawczą zabawki, która stając się często bohaterką powiastek, przygotowuje czytelnika do odpowiedniego funkcjonowania w społeczeństwie, pełnienia oczekiwanych społecznie ról. Po drugie, dopiero w tekstach dziecięcych można dostrzec zarówno emocje, jakie wzbudzały w dzieciach zabawki, jak też

${ }^{14}$ Gwiazdka, „Nasza Gazetka: przyjaciel, nauczyciel i przewodnik. Dodatek do Nadgoplanina" 1888, nr 11, s. 42.

${ }^{15}$ E.J., Zabawki dziecinne, „Kłosy” 1885, nr 1068, nr 395.

${ }^{16}$ Oświeceniowy pisarz i działacz społeczny, Michał Dymitr Krajewski, pisał: „To szczególnie za cel wziąłem sobie, abym bawiąc pożytecznie wiek młody, od pierwszych lat sposobił go do nauk, i słodząc mu je różnymi rozrywkami, wkorzeniał w nich gust i miłość tego, co ma być w dalszym czasie największym jego uszczęśliwieniem" [w:] M.D. Krajewski, Gry nauk dla dzieci stużące do ułatwienia ich edukacji, przez które łatwo nauczyć się moga poznawania liter, sylabizowania, czytania w polskim i francuskim języku, formowania charakteru pisania, języków ze zwyczaju, historii, geografii i początków arytmetyki, Kraków 1777, s. 1.

17 Z. Seidlerowa, O zabawkach, „Bluszcz” 1904, nr 50, s. 590. 
odnaleźć opisy samych zabaw z ich wykorzystaniem. Tych ostatnich próżno szukać w innych źródłach.

Powiastki, bajeczki, czy wierszyki dla najmłodszych - publikowane zarówno w formie książeczek, jak i teksty umieszczane w czasopismach dla dzieci - stanowią wartościowe poznawczo źródło do badania zabawek świątecznych. Autorzy chętnie wykorzystywali okres świąt Bożego Narodzenia, czyniąc go tłem dla fabuły opowiadanych małym czytelnikom historyjek. Pisano nawet specjalnie z tej okazji okolicznościowe obrazki, nowelki, czy wierszyki. Zwykle historie takie opowiadały o przygotowaniach do świąt, świątecznej atmosferze, chwilach wspólnie spędzanych z rodziną, a w części z nich znajdujemy też informacje o otrzymywanych pod choinkę czy na kolędę zabawkach i cackach. Autorzy opisywali nie tylko rodzaje wymarzonych przez dzieci w danym okresie zabawek, ale też ich wygląd, sposoby wykorzystania w czasie organizowania różnych zabaw, atmosferę towarzyszącą oczekiwaniu na prezent. Bywało, że całe, osobne powiastki czy wiersze poświęcano zabawce bądź zabawkom, a także, co interesujące z naszego punktu widzenia, przedstawiano sposoby zabawy otrzymanymi przedmiotami.

Najczęściej ukazywano praktyczne wykorzystanie zabawki.

Z taką sytuacją mamy często do czynienia w literaturze intencjonalnie kierowanej do młodych odbiorców, gdzie sceny prezentujące tego typu zachowania pełniły funkcję instruktażową, ilustrowały wychowawczy charakter różnorakich dziecięcych działań, wskazywały na konieczność przygotowania się do przyszłego dorosłego życia, pełnienia w nim określonych lub zaledwie sugerowanych ról społecznych i rodzinnych ${ }^{18}$.

Sama zabawka (jej wygląd, produkcja, wartość itp.), a także zabawa nią były determinowane społeczną pozycją dziecka - jego statusem materialnym, wychowaniem, systemem wartości i tym podobnym. W tych tekstach o jednoznacznych przesłaniach zabawki jawią się jako najważniejsze przedmioty dzieciństwa, wymarzone rzeczy, kreujące codzienną rzeczywistość.

Zarówno w utworach poetyckich, jak i powiastkach oraz innego rodzaju tekstach publikowanych w czasopismach dla dzieci można zauważyć kilka wspólnych elementów. Po pierwsze, występuje osoba czy postać (Święty Mikołaj, Gwiazdor, krewni, Aniołek) dająca zabawkę. Po drugie, ukazany jest różny czas obdarowywania prezentami - okres ten na przełomie XIX i XX wieku trwał od 6 grudnia do 6 stycznia. Po trzecie, po spotkaniu się dziecka ze Świętym Mikołajem lub Gwiazdorem musiało ono przejść przez pewne rytuały: na przykład odmówić pacierz, potwierdzić, że cały rok było grzeczne, słuchało rodziców i tym podobne. Po czwarte, widoczny jest wyraźny podział na zabawki dla dziewczynek i chłopców. W powiastce „Pogadanki

${ }^{18}$ G. Leszczyński, Kulturowy obraz dziecka i dzieciństwa w literaturze drugiej połowy XIX i w XX wieku, s. 138. 
braci z siostrami, spisane ku zabawie młodych czytelników" poznajemy rodzeństwo: Emila i Amelkę, którzy opowiadają, co kupiliby sobie nawzajem na kolędę, gdyby oczywiście mieli pieniądze. Chłopczyk kupiłby siostrze

wielką lalkę, którą widziałem w sklepie o kilka domów od nas i która mówi i „mama” i „Papa”, a dziewczynka kupiłaby bratu wielocyped, podkreślając, że otrzymałby go jedynie w wypadku, jeśli byłby grzeczny ${ }^{19}$.

I wreszcie, w różnych tekstach adresowanych do dzieci poruszano ważną wychowawczo kwestię - dzielenia się zabawkami z biednymi dziećmi.

Na zakończenie wstępnych refleksji należy zadać sobie pytanie: Jak słownikowo definiowano zabawkę w II połowie XIX i na początku XX wieku? Trudno znaleźć definicję satysfakcjonującą współczesnego badacza. W źródłach słownikowych zabawkami były nazywane przedmioty służące dzieciom do zabawy. Na przykład, Słownik jezyka polskiego Samuela Bogusława Linde z 1814 roku zabawkami określał: „zabaweczki, którymi dzieci się bawią, lalki itp." ${ }^{20}$, natomiast definicja zabawki znajdująca się w Słowniku języka polskiego z roku 1861 ma kilka znaczeń. Z punktu widzenia naszych rozważań, ważne są dwa: pierwsze - „przedmiot do zabawy, rozrywki” oraz drugie - „rzecz drobna, umyślnie dla zabawy dzieci robiona, np. lalki, koniki, itp." ${ }^{21}$. W Słowniku jezzyka polskiego podtug Lindego i innych nowszych źródeł Erazma Rykaczewskiego z 1866 roku termin zabawka ma dwa znaczenia. Pierwsze: „zdrob. mała zabawa, mała rozrywka”, drugie „to, czem się dzieci bawią. Kupiłem mu drewnianego konika na zabawkę" 22. W 1869 roku jeden z przewodników higienicznych podawał: „przedmioty, które dzieciom do zabawy służą, nazywamy zabawkami”23. Celem zabawek było zaś „dostarczenie

${ }^{19}$ L. Biart, Pogadanki braci z siostrami, spisane ku zabawie młodych czytelników, przełożył J. Chęciński, Warszawa 1875, s. 177-178. Lalka, narratorka powiastki „Pamiętnik lalki przez Walentynę z Trojanowskich Horoszkiewiczową", zakupiona w dzień Wigilii na prezent gwiazdkowy dla Wandzi ze szczegółami opisała prezenty dla Wandzi i jej brata Stasia - zabawki: gotowalnię (toaletkę) dla lalek z krzesełkiem, umeblowany lalczyny pokoik, ubranka dla lalki, zastawę do herbaty, porcelanowy serwis, powóz, konika na kółkach, biczyk i szabelkę oraz książeczki.

${ }_{20}$ Stownik jezzyka polskiego przez M.S.B. Linde, t. VI, U-Z, Warszawa 1814, s. 592.

21 Stownik języka polskiego, obejmujący oprócz zbioru właściwie polskich, znaczną liczbę wyrazów z obcych języków [...] do podręcznego użytku, cz. 2, P-̇̇, Wilno 1861, s. 2063; W słowniku tym można również znaleźć określenie „zabaweczka” - z kwalifikatorem „pieszcz. [...] zabawka”. Z hasłem tym koresponduje następne w kolejności: „Zabawkowy, [...] służący do zabawienia, od zabawek dziecinnych", tamże, s. 2063.

${ }^{22}$ E. Rykaczewski, Słownik języka polskiego podtug Lindego i innych nowszych źródet, t. II, Berlin-Poznań 1866, s. 1056.

23 Przewodnik w zdrowym pielegnowaniu dzieci od przyjścia na świat aż do dojrzenia, skreślony przez przyjaciela dzieci (lekarza), Lwów 1869, s. 84. Z kolei Słownik języka polskiego z 1927 r. pod redakcją Jana Karłowicza, Adama Kryńskiego i Władysława Niedźwiedzkiego zabawką określał „przedmiot do zabawiania dzieci, cacko, zabaweczka, np. konik, lalka”, Słownik języka polskiego, red. J. Karłowicz, A. Kryński, W. Niedźwiedzki, Warszawa 1927, z. 44, s. 17. 
dzieciom przyjemnych wrażeń, przyczyniających się bądź to pośrednio, bądź bezpośrednio do pomyślnego rozwoju władz fizycznych i umysłowych" ${ }^{24}$. $W$ niniejszych rozważaniach, na podstawie analizy znaczeń terminu zabawka z XIX i początku XX wieku, przyjęto, że zabawką będzie przedmiot celowo wyprodukowany do zabawy ${ }^{25}$.

\section{Kto i kiedy obdarowywał dzieci prezentami?}

W różnego rodzaju tekstach (prozatorskich, wierszowanych, ikonograficznych) adresowanych do dzieci można znaleźć informacje dotyczące osób przynoszących prezenty. Co ważne, podarki otrzymywać miały jedynie te $\mathrm{z}$ dzieci, które przez cały rok były dobre, posłuszne rodzicom, pilne w nauce i żyjące w zgodzie z rodzeństwem. Tylko dla takich dzieci Święty Mikołaj, Gwiazdor, Gwiazdka, Aniołek, czy Jezusek mieli wymarzone zabawki. W wierszyku zatytułowanym „Boże drzewko” piękne zabawki zawieszone na choince - pajace, lalki, trąbki, piszczałki, koniki, a także ozdoby, słodycze i inne cacka otrzymały dzieci w nagrodę za dobre sprawowanie i posłuszeństwo rodzicom.

Drzewko, drzewko! Klaszczą w dłonie

Ucieszone dzieci.

Co tu wisi różnych cacek,

Co tu świateł świeci.

Tu orzechy, tam jabłuszka

Złote, posrebrzane,

Tu cukierki i pierniczki,

Jakby malowane.

A tu różne zabaweczki,

Piszczałki, koniki,

Trąbki, lalki, świstaweczki,

Różne pajacyki.

Patrzcie dzieci - mówi matka,

Wszystkie cacka one,

Żeście były zawsze grzeczne

Dla Was zawieszone.

${ }^{24}$ R. Rogożewski, Jakie zabawki kupować dzieciom, „Dziecko” 1913, nr 9, s. 533. Por. M. Nawrot-Borowska, K. Kabacińska-Łuczak, Co podarować dziecku na Gwiazdkę?

${ }^{25}$ Por. K. Kabacińska-Łuczak, M. Nawrot-Borowska, Dziecięce zabawki świąteczne...; także porównaj współczesną definicję zabawki autorstwa Jana Bujaka: „przedmiot materialny specjalnie wykonany do celów zabawowych, który zawiera w sobie treści kulturowe właściwej dla niego epoki lub epok minionych z zakresu kultury materialnej, duchowej lub społecznej i przekazuje je w sposób budzący określone postawy ludyczny, a za ich pośrednictwem kształtuje rozwój fizyczny, psychiczny lub emocjonalny"; J. Bujak, Zabawki w Europie. Zarys dziejów - rozwój zainteresowań, Kraków 1988, s. 15. 
Bo to dzieci od Jezuska

Na drzewko dostają,

Co są pilne, tatę, mamę

Cały rok słuchają.

I dzieciaki, ze łzą w oku,

Mamę uściskały,

Jezusowi za te dary,

Wdzięcznie zaśpiewały ${ }^{26}$.

Jedną z postaci przynoszących prezenty był Gwiazdor, „siwy staruszek z siwą brodą, w kożuchu.

No, dzieci! - zawołał - najprzód pacierz, a potem każdy dostanie, co mu się należy. Pierwszy wypowiedział „Ojcze Nasz” bez zmyłki Jędrek i dostał książkę z obrazkami, stajnię i wózek, za nim drżącym trochę głosikiem wyszeptała swój krótki paciorek Zochna, za co „Gwiazdor" dał jej lalkę i łóżeczko, trzecia z kolei stała Baśka. „Gwiazdor" podał jej dawno upragnioną małą maszynę do szycia, w drugiej ręce trzymał serwis do herbaty ${ }^{27}$.

Pan Gwiazdor zjeżdża z gór, W wieńcu ze srebrnych piór.

Latarnią sobie świeci I spieszy się do dzieci. Zabawek wiezie moc $\mathrm{W}$ tę wigilijną noc.

Książki, lalki i koniki, Bębny, piłki i pierniki (...) Złotą latarnia miga, W ręku zabawki dźwiga (...) I pyta Gwiazdor miły, Czy dzieci grzeczne były?

A grzeczne tu i tam

Kolędę daje sam.

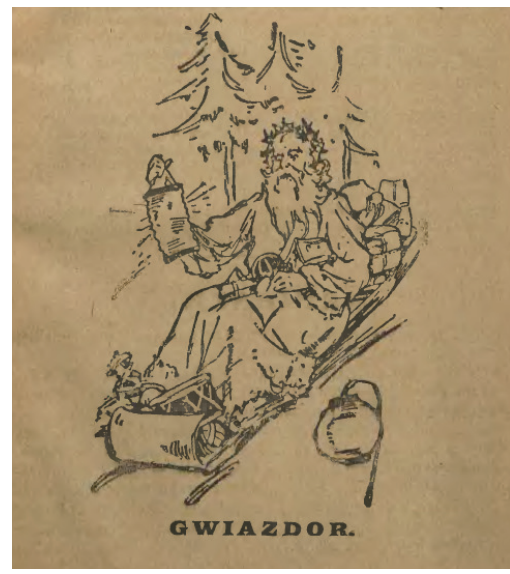

\section{Ryc. 1. Gwiazdor}

(Źródło: „Dzwonek. Gazetka dla dzieci. Bezpłatny dodatek dwutygodniowy do Katolika” 1911, nr 26, s. 1-2)

Na grafice (ryc. 1), będącej ilustracją wiersza, przedstawiono Gwiazdora jadącego saniami do (grzecznych) dzieci. Wiezie on na nich liczne pakunki, pośród których wyraźnie widać zabawki - piłki, duży bębenek, figurkę zwierzęcia.

${ }^{26}$ Boże drzewko, „Dzwonek. Gazetka dla dzieci. Bezpłatny dodatek dwutygodniowy do Katolika" 1910, nr 26, s. 3-4.

27 B. Włodkówna, Czy Baśka dobrze zrobiła? „Światek Dziecięcy” 1910, nr 5, s. 34-35. 
Równie często prezenty przynosił Święty Mikołaj - starszy mężczyzna z siwą, długą brodą, który najpierw pytał, czy dzieci były grzeczne, sprawdzał, czy umieją paciorek i dopiero wówczas dawał wymarzone zabawki.

W wielu okolicach bywa dzień św. Mikołaja (6 Grudnia) dla dzieci tem, czem wigilia Bożego Narodzenia czyli Gwiazdka. Zaledwie się miesiąc grudzień napocznie, już sobie dzieci opowiadają o Św. Mikołaju, wielkim przyjacielu dzieci, jak w dzień swego święta chodzi po świecie i obdziela dzieci podarkami. Niejedno dziecko staje się wtenczas grzeczniejszem, gdyż święty biskup tylko grzecznym dzieciom daje podarki ${ }^{28}$.

\section{Święty Mikołaj miał jednak nie tylko prezenty, ale także rózgę}

na dzieci nieposłuszne i nie chcące się uczyć, zwłaszcza na te polskie dzieci, co do polskiego czytania i pisania są leniwe ${ }^{29}$.

Grafika (ryc. 2) ilustrująca tekst opisujący postać świętego, obrazuje Mikołaja w biskupim stroju, w towarzystwie Anioła (przynoszącego prezenty pod choinkę w Galicji), którzy $\mathrm{w}$ dłoniach niosą prezenty dla dzieci - oczywiście zabawki. Widzimy lalki, skaczącego pajaca, konika, biczyk, wózki i zwierzątka na kółkach, domki, piłki (anioł trzyma piłkę w siatce), łuk, trąbkę, armatkę, a więc całe bogactwo najpopularniejszych i z pewnością najbardziej wymarzonych zabawek dziecięcych.

$$
\begin{gathered}
\text { Ryc. 2. Święty Mikołaj } \\
\text { (Źródło: „Moje Pisemko” 1903, nr 10, s. 145) }
\end{gathered}
$$

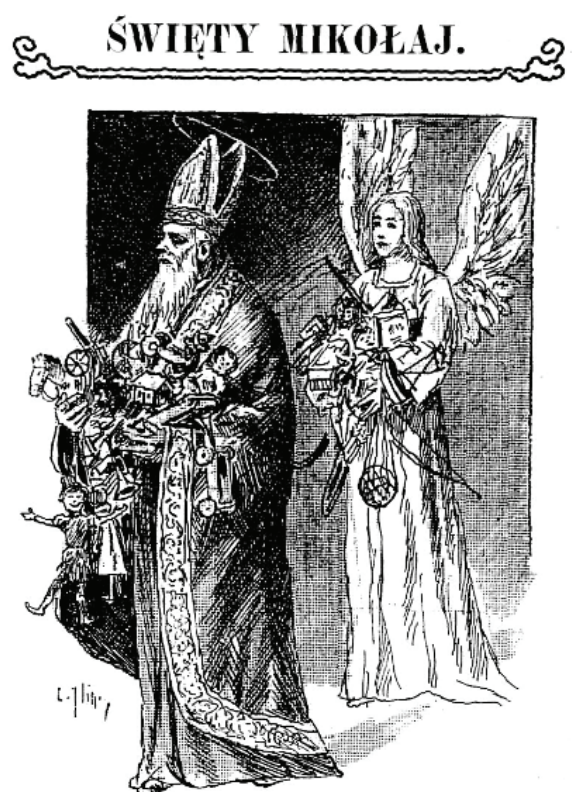

${ }^{28}$ Dzień Świętego Mikołaja, „Światło” 1892, nr 24, s. 382; Na łamach „Mojego Pisemka” w 1903 roku czytamy, iż obchodzenie dnia Świętego Mikołaja miało miejsce »od niepamiętnych czasów « w Krakowie, w Galicji, zaś w Warszawie nie było praktykowane. Święty Mikołaj, patron dzieci biednych, przychodził w wigilię 6 grudnia - to oczywiście matka wsuwała śpiącemu już dziecku pod poduszkę podarunki, które zakupić mogła na Małym Rynku, placu obok kościoła Maryi Panny. Tam to tradycyjnie przekupki sprzedawały lalki, drobne zabawki, złocone jabłka i orzechy oraz różnej wielkości pierniki w kształcie świętego, zwane mikołajkami. Krakowskim zwyczajem było też chodzenie wieczorem 5 grudnia po domach przebierańców, św. Mikołaja, anioła i diabła. Anioł niósł kosz pełen zabawek i pierników, obdarzając dzieci upominkami, za które oczywiście rodzice płacili, Święty Mikołaj, „Moje Pisemko” 1903, nr 10, s. 145-146; zob. też: Święty Mikołaj, „Dzwonek. Gazetka dla dzieci. Bezpłatny dodatek dwutygodniowy do Katolika" 1905, nr 25, s. 197-199.

${ }^{29}$ Tamże. 
Także w wierszu „Otrzymywanie zabawek” umieszczonym w zbiorze Złoty wiek dziecięcy. Wierszyki i obrazki dla małych dziatek oraz na grafice umieszczonej obok tekstu można znaleźć wskazania, komu Mikołaj i Choinka (w Boże Narodzenie) mogą dać prezenty. Podstawowym wymogiem jest bycie grzecznym i posłusznym rodzicom.

Gdy dzieci dobre, grzeczne i łagodne

A nie grymaszą i z rodzeństwem zgodne,

Wtedy Mikotaj święty w białej brodzie,

Przychodzi do nich po słońca zachodzie.

I daje wiele pięknych rzeczy - wiele!

Dla ślicznych lalek krzesełka fotele,

Stoły, garnuszki, dzbanki i miseczki,

Dla chłopców szable, żołnierzy. Piłeczki.

Nie koniec na tym - W Narodzenie Boże

Znowu się zjawia o cichym wieczorze

Choinka śliczna dla waszej uciechy,

Ubrana w jabłka, cukierki, orzechy,

A pod nią w blasku tych świeczek, co płoną

Mnóstwo prezentów dla was położono;

Więc się ciesz dziatwo, bo Święta Dziecina

O grzecznych dzieciach swych nie zapomina ${ }^{30}$.
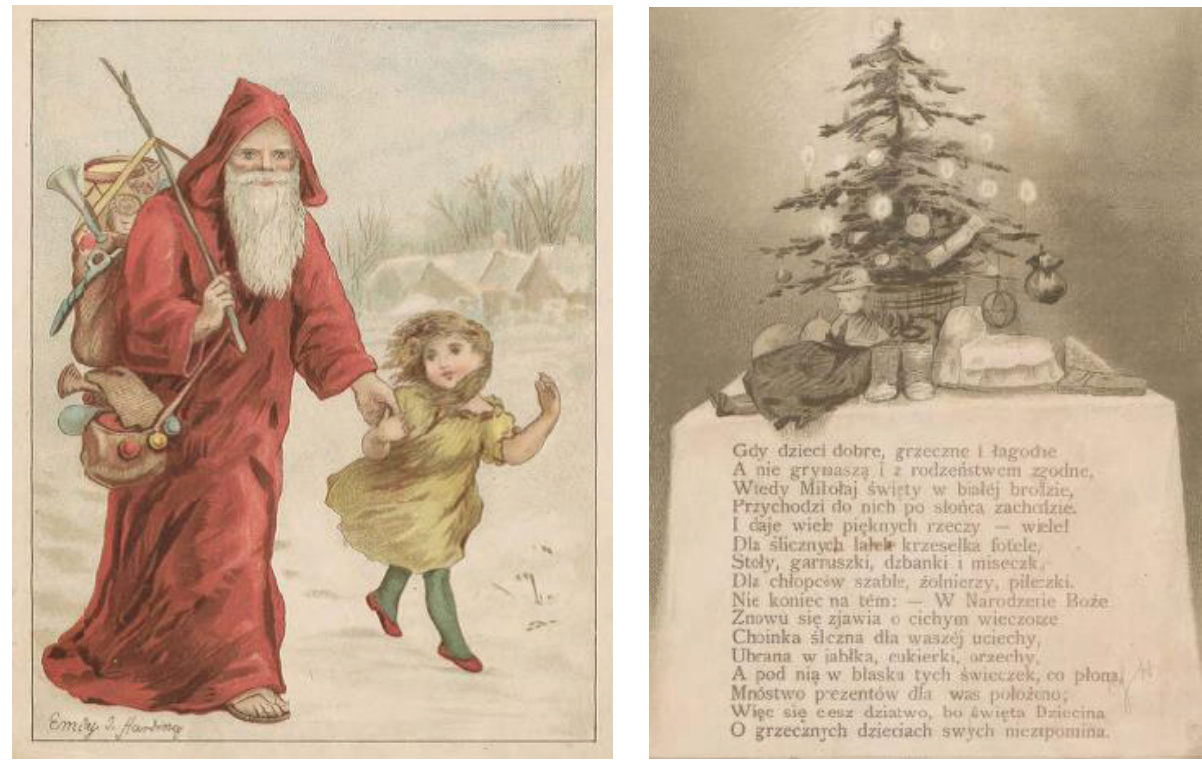

Ryc. 3. Złoty wiek dziecięcy. Wierszyki i obrazki dla matych dziatek

(Źródło: Kraków 1890, s. 12-13)

${ }^{30}$ Złoty wiek dziecięcy. Wierszyki i obrazki dla matych dziatek, Kraków 1890, s. 13. 
Co interesujące, $\mathrm{w}$ tekście tym zawarta jest informacja o kolejnym dniu wręczania prezentów, czyli dniu Bożego Narodzenia. Tym razem nie przychodzi żadna postać przynosząca podarki, tylko dzieci znajdują je pod choinką. Także pod nią ustawiała prezenty Gwiazdka, która

zstępując w noc wigilijną na ziemię, przybiera postać ślicznej, bogatej pani - anioła, z całym orszakiem malutkich aniołków, dźwigających mnóstwo podarków, ustawia je w zamkniętym pokoju na stole koło zielonego drzewka, płonącego tysiącem barwnych świeczek, i czeka, aż wejdą do pokoju dzieci, a ucieszywszy się ich radością, dopiero spieszy obdarować inne ${ }^{31}$.

Jedna z powiastek wyraźnie wyjaśnia najmłodszym, co oznacza bycie grzecznym, co ma dać gwarancję otrzymania prezentów gwiazdkowych pięknych zabawek.

Otulona w długi, śnieżny płaszcz, z kapturkiem zarzuconym na głowę obchodziła Gwiazdka w mroźny dzień grudniowy wszystkie domy, wszystkie mieszkania, gdzie tylko były dzieci, by przekonać się czy grzecznym zachowaniem się zasłużyły na jej dary w dzień wigilijny. O, bo dobre dzieci to takie, które są radością swych rodziców, nigdy nie kłamią, w porządku trzymają swe zabawki i książeczki, takie dzieci Gwiazdka kocha bardzo i cieszy się, gdy może ich nagrodzić. A bywa nieraz bardzo hojna. Każdemu chce dogodzić, każdemu dać, co najwięcej pragnie. Śliczne, strojne lalki od największej do najmniejszej, koniki kare, siwe, bułane, wózki, karety, tramwaje, pudełka z klockami, przeróżne gry, książeczki. Wszystko gotowa rozdać dla tym większej radości, dla większego uszczęśliwienia dzieci w dzień wigilijny ${ }^{32}$.
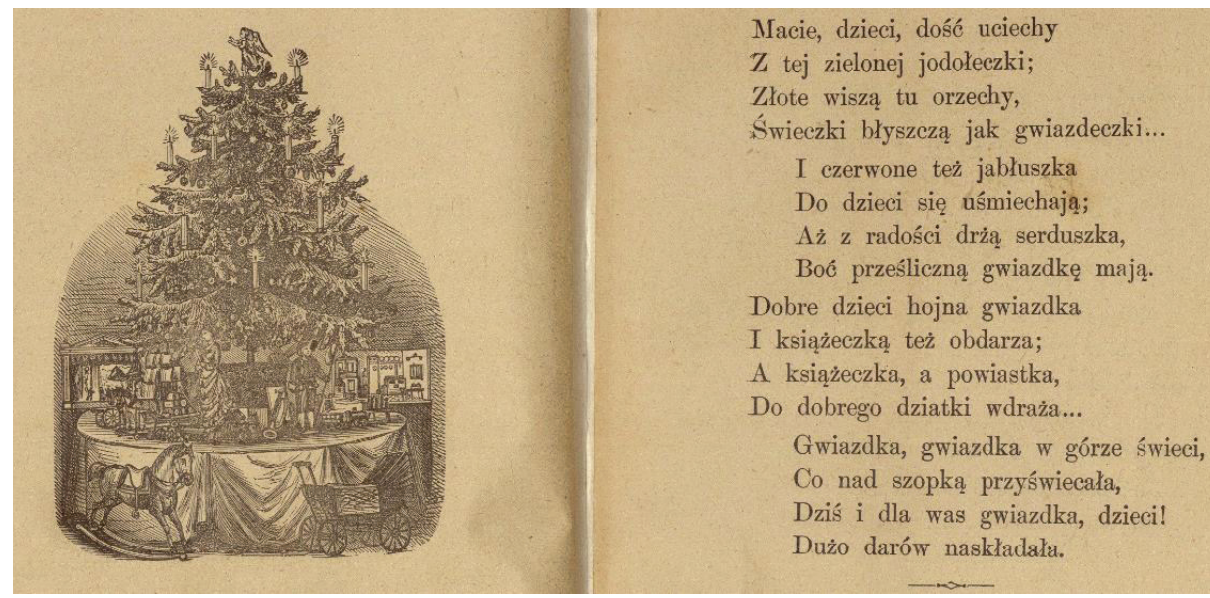

Ryc. 4. Piosenka o choince

(Źródło: Upominek z prac Jachowicza. Bajki, nauczki, opisy, powiastki i różne wierszyki z 40 obrazkami, wyd. III, Poznań 1902, s. 64-65)

${ }^{31}$ Gwiazdka Przewodniczka, „Wieczory Rodzinne. Tygodnik Ilustrowany dla Dzieci” 1888, nr 51, s. 403.

${ }^{32}$ Dary gwiazdki, „Wieczory Rodzinne” 1901, nr 51, s. 202. 
Pod choinką (ryc. 4) widać prawdziwe bogactwo dziecięcych zabawek. Są tam zarówno zabawki dla dziewczynek, jak i dla chłopców. Na stole pod choinką postawiono lalkę $\mathrm{w}$ pięknej sukni, pokoik $\mathrm{z}$ mebelkami do zabawy laleczkami, teatrzyk, wózek dzwonkowy, koniki na platformach z kółkami. Jest także lalka-żołnierz, kolejka, statek z żaglami, trąbka. Przy stole ustawiono duży, wiklinowy wózek dla lalek i konika na biegunach ${ }^{33}$.

Podobne przedstawienie pięknie przyozdobionej choinki zostało umieszczone w "Wieczorach Rodzinnych. Tygodniku Ilustrowanym dla Dzieci" (1885). Zamyślona dziewczynka poprawia dekoracje choinkowe. Pod drzewkiem, na podłodze czekają na dzieci zabawki: dla chłopca jest tam konik na biegunach, szabelka, bębenek, natomiast na dziewczynkę czeka lalka, a także książeczka i piłka.

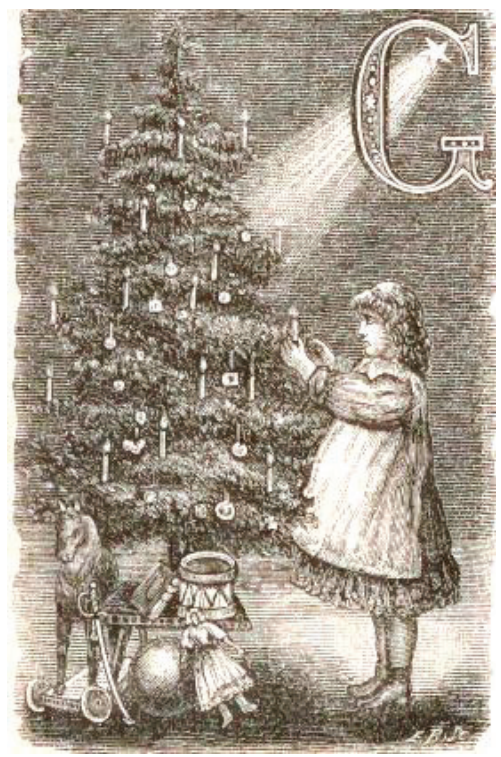

Ryc. 5. Kolenda

(Źródło: „Wieczory Rodzinne. Tygodnik Ilustrowany dla Dzieci” 1885, nr 52, s. 409)

Także w „Wieczorach Rodzinnych” (1902) została przedstawiona scena przy choince (ryc. 6). Zapewne przed upamiętnieniem tej chwili, dzieci otrzymały zabawki. Rodzeństwo z radością podnosi je do góry i pokazuje ojcu, który z lekkim uśmiechem przytula uradowane pociechy. Jeden chłopiec trzyma armatkę, natomiast drugie dziecko zajączka. Pod pięknie udekorowanym drzewkiem umieszczono wiele zabawek; dla chłopca jest tam między innymi konik w zaprzęgu ciągnący wóz.

${ }^{33}$ Piosenka o choince, [w:] Upominek z prac Jachowicza. Bajki, nauczki, opisy, powiastki i różne wierszyki z 4 obrazkami, wyd. III, Poznań 1902, s. 64-65. 


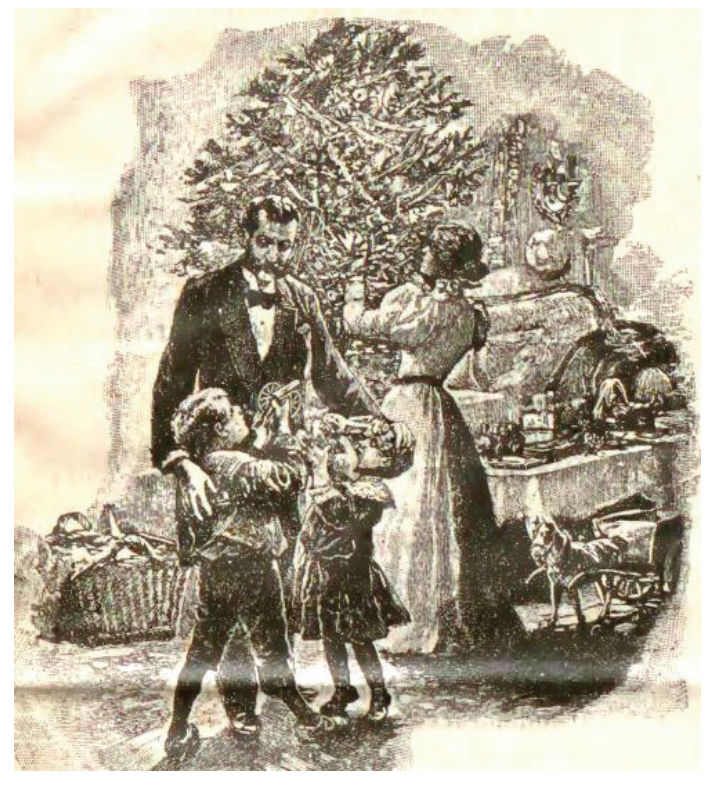

Pod choinką

W noc Bożego Narodzenia, Srebrnopióry anioł leci. Od złotego gwiazd promienia Zapala choinki dzieci.

Pod choinką ileż gwaru Radosnego i uciechy! Roziskrzone błyszczą oczy, I dziecięce dzwonią śmiechy. O czym nieraz przez rok cały Serduszko dziecięce marzy, Znajdzie dzisiaj pod choinką Co się łuną świateł jarzy.

Ryc. 6. Pod choinka

(Źródło: „Wieczory Rodzinne. Tygodnik Ilustrowany dla Młodzieży i Dzieci” 1902, nr 51, s. 201)

W Wigilię pod choinką zostały ustawione, ku uciesze dzieci, prezenty. Taki moment opisuje lalka - narratorka powiastki „Pamiętnik lalki przez Walentynę z Trojanowskich Horoszkiewiczową":

O któreż z was kochane dzieci nie zna wilii Bożego Narodzenia! Które nie wie, że staropolskim zwyczajem, dziś jeszcze w wielu domach zachowanym ukazanie się pierwszej gwiazdki na niebie jest znakiem zaczęcia sutego obiadu (...) Któreżby zapomniało, że (...) grzeczne dzieci od kochanych rodziców dostają zasłużone podarunki, i że zwyczaj ten z tą chwilą, jakby dla wywdzięczenia się dobroczynnemu światełku, co jej zbliżenie oznacza, gwiazdką przezwano. Na gwiazdkę więc i ja byłam przeznaczona (...) Na środku salonu (...) stał duży okrągły stół. Na nim wysokie świerkowe drzewko, ustrojone mnóstwem zapalonych świeczek, gałązki jego zakończone złoconymi orzechami, nosiły na sobie czerwone jabłuszka i koszyczki, pełno cukierków i różnych łakotek. Po prawej stronie stała śliczna gotowalnia maleńka, na niej poduszeczek, flakoników, kwiatów bez liku, przed zwierciadełkiem w dwóch lichtarzykach błyszczących zapalono obrotowe świeczki - a przed gotowalnią wygodne, aksamitem pokryte krzesło z poręczami. Po lewej stronie stał koczyk zgrabny ze spuszczającą się budą i zamykanymi drzwiczkami, konik osiodłany z kółkami u nóżek, biczyk i szabelka z pendentem. Posadzono mnie na krześle przed gotowalnią (...) Od babuni zastawa do herbaty i serwis porcelanowy, od wujaszka trzy tomy powiastek Jachowicza, a od starszej siostry prześlicznych, rozmaitych kawałków pudełko i obrazki do historii polskiej ${ }^{34}$.

${ }^{34}$ Pamiętnik lalki przez Walentyne z Trojanowskich Horoszkiewiczowa, Warszawa - Kraków Lwów 1907, s. 7-8. 
Oprócz rodziców, dzieci otrzymywały prezenty także od innych bliskich - dziadków, rodzeństwa, czy wujków.

W jednej z powiastek, opublikowanej w świątecznym numerze „Dzwonka”, dzieci dowiedziawszy się o wizycie ukochanego dziadka, licytowały się, kto, jaki podarek otrzyma. Dziadek bowiem miał w zwyczaju dorocznie odwiedzać wnuki w okresie Świąt, przywożąc dla nich na tak zwaną Gwiazdkę piękne zabawki.

- A co byś ty chciał dostać od dziadzia?

- Ja? Klocki do budowania domów.

- A ja konia na biegunach!

- Ja to na pewno dostane lalkę! Pewnie dużą! Żeby tylko umiała zamykać oczki i żeby miała długie, jasne włosy! ${ }^{35}$

Wnioskując z oczekiwań dzieci, dziadek przywoził wnukom zabawki wartościowe, prawdopodobnie sprowadzane z zagranicy.

W tekstach adresowanych do dzieci często można znaleźć opisy ich wielkiego zachwytu nad zabawkami znajdowanymi pod choinką. Za przykład niech posłuży scena opisana w opowiadaniu „Niezapominajki”.

Byliśmy grzeczni już kilka dni...może przez tydzień...ale Pan Jezus cały rok na nas patrzał i wszystko pamięta. Możeśmy nie zasłużyli? (...) Dziń, dziń, dziń, odezwał się dzwonek trzykrotnie. Dzieci zerwały się drżące trwogą i radością. (...) A, ach! Więcej nie mogli malcy wymówić w pierwszej chwili. Mama wzięła Adasia za rękę, tatuś Zosię i zaprowadzili ich do bawialnego pokoju. Na samym środku pokoju stała duża choinka iskrząca się mnóstwem świeczek, obwieszona przysmaczkami, a na posadzce dookoła drzewka aż roiło się od zabawek. O, konik! O, lalka! O, szabelka! O, kuchenka! Bęben..., trąbka..., kanwa..., włóczki..., wózek..., krówka z cielątkiem..., piłka...! Ach, jaki Pan Jezus dobry! Takie nam śliczne rzeczy przez aniołka przysłał! ${ }^{36}$

Podobna scena została ukazana na rycinie 7. Na grafice tej uwieczniono moment zachwytu dzieci nad piękną choinką (dziewczynki z radością, z uniesionymi rączkami podchodzą do błyszczącego drzewka) oraz nad leżącymi pod nią zabawkami. Na prezenty zwrócił uwagę chłopczyk, którego nie interesują ozdoby choinkowe i roziskrzone świece, ale podarki. Pochyla się i wyciąga rączkę, zapewne po czekającą na niego kolejkę z trzema wagonikami. Pod drzewkiem znajdują się również inne zabawki - oczywiście lalka dla którejś z dziewczynek, a także domek, kuchenka, lalczyny serwis do kawy i książeczki.

35 Piękny podarunek, „Dzwonek. Gazetka dla dzieci. Bezpłatny dodatek dwutygodniowy do Katolika" 1909, nr 26, s. 7.

${ }^{36}$ Niezapominajki, „Dodatek do Numeru 51-go Wieczorów Rodzinnych” 1891, s. 203. 


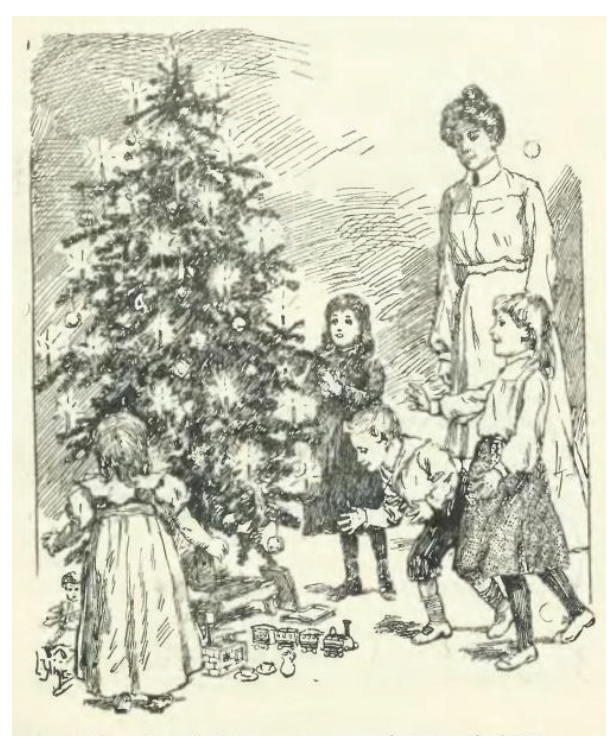

Ryc. 7. Świateczne prezenty

(Źródło: „Moje Pisemko” 1908, nr 13)

\section{Zabawki dla chłopców}

Podział zabawek ze względu na płeć dzieci można chyba najbardziej dostrzec $w$ tekstach intencjonalnie kierowanych do dzieci. Wynikało to zapewne z propagowania oczekiwanych i akceptowanych społecznie zachowań, czyli przygotowania dzieci do pełnienia ról odpowiednich dla swojej płci i zdeterminowanych sytuacją społeczno-finansową rodziny. I tak, chłopcy mieli kształtować swoje umiejętności praktyczne (budowanie domu, tworzenie ogrodu, prowadzenie gospodarstwa itp.), przygotowywać się do podjęcia walki za ojczyznę (jazda na konikach, zabawa w żołnierzy).

Przykładem chłopca, który marzy o różnych narzędziach jest podmiot liryczny wiersza zatytułowanego „Narzędzia”:

Gdybym ja tak klocki dostał,

To bym pierwszym majstrom sprostał:

Bom bym ślicznie wybudował

Od podłogi aż pod pował.

Z bramą, drzwiami i oknami,

Zobaczylibyście sami.

Potem zapytałbym

Kto zamieszka w nim. 


\begin{abstract}
A ja gdybym miał deszczułki, To bym zbił prawdziwe półki. Wziąłbym dłutka i lauzbegi, Poobcinał ślicznie brzegi. Potem półki wyrzynane Poprzywieszałbym na ścianę. I tam książki kładł, By mieć w rzeczach ład.

A ja chciałbym dostać taczki. Rydel, grabie, polewaczki, By w ogrodzie móc pracować, Siać i sadzić i flancować.

Po rządeczku, w porządeczku, Równo kwiatek przy kwiateczku.

A gdy przyjdzie maj, Grzędy mieć jak gaj ${ }^{37}$.
\end{abstract}

Bronek, bohater „Obrazków z pożycia dobrej rodziny”, z utęsknieniem czekał na świąteczne prezenty, tym bardziej że wraz z siostrą Izabelą widział, że mama odebrała sporych rozmiarów skrzynię z Berlina. Dzieci domyśliły się, że mogą w niej być prezenty. „Oczekiwania były tym większe. Podarunki z Berlina! Co to za śliczne bez wątpienia są rzeczy!"38. W Wigilię matka wraz z ojcem otworzyli pokój

do dziecinnego pokoju, w którym na stole, piękną serwetą przykrytym, poustawiane były różne podarunki (...) Ach, to dla mnie - zawołał Broniś, i porwał się do blaszanej szabelki, która leżała na stoliku, ja będę generałem! I to także dla Ciebie, rzekła matka, wskazując na ogromnego z brodą francuskiego sapera i ta armata i ta fuzja $(\ldots)^{39}$.

W powiastce „Bitwa Francuzów z Prusakami” rodzeństwo otrzymało od ukochanego wujaszka mnóstwo rozmaitych zabawek - Adaś trąbkę, fuzyjkę i pudełeczko z kapiszonami. Oprócz tego trzy pudełka doskonałych cukierków. Radość była ogólna ${ }^{40}$.

Podobnie radość dzieci z otrzymanych zabawek można dostrzec na grafice (ryc. 8) z 1864 roku, umieszczonej w „Przyjacielu Dzieci”. Ta rodzinna scena pokazuje, $\mathrm{w}$ jaki sposób dzieci dziękowały rodzicom za prezenty (chłopiec całuje ojca $w$ rękę). Drugi chłopczyk z radością już przyczepił szablę do swego boku, podnosi konika na biegunach, zapewne już w wyobraźni jest pędzącym na rumaku zwycięzcą. Na stole stoi jeszcze jedna zabawka chło-

${ }^{37}$ Narzędzia, [w:] B. Ostrowska, Gwiazdka polskiego dziecka, Warszawa 1924, s. 11

${ }^{38}$ F.H. Lewestam, Obrazki z pożycia dobrej rodziny, Warszawa 1844.

39 Tamże, s. 66-72.

${ }^{40}$ M. Brühlowa, Bitwa Francuzów z Prusakami, „Dodatek do numeru 50-go Wieczorów Rodzinnych" 1889, s. 193. 


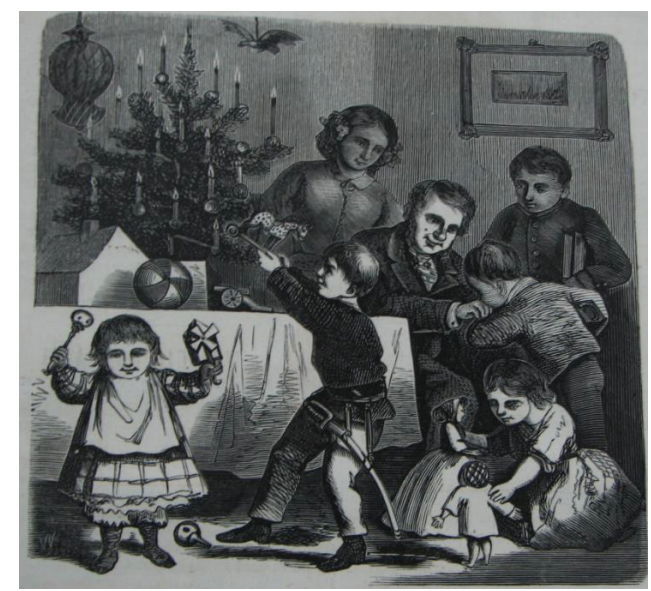

Ryc. 8. Zabawa

(Źródło: „Przyjaciel Dzieci” 1864, nr 195, s. 1)

pięca - armata. Dziewczynka bawi się lalkami, a najmłodsze dziecko trzyma w rączce grzechotkę i wiatraczek.

Inną wymarzoną chłopięcą zabawką był bębenek. Michaś marzył o zabawce, którą mieli wszyscy jego koledzy. Mama nie chciała kupić jej chłopcu ze względu na babcię, której hałas bębnienia przeszkadzałby w odpoczynku. Michaś otrzymał jednak upragnioną zabawkę od wujka, który przyjechał na święta do rodziny do Warszawy i podarował ją chłopcu na Nowy Rok. Obdarowany obiecał jednak bawić się prezentem tylko wówczas, kiedy babcia będzie wychodziła lub wyjeżdżała. I obietnicy dotrzymał. Kiedy nie było babci,

chłopczyk przewieszał bębenek na tasiemce przez plecy, wkładał na główkę mufkę maminą (...) brał w ręce obie pałeczki i dopiero po całym domu rozchodziło się głośne bum, bum bum (...) Tak to dobry Michaś nawykł od dzieciństwa powstrzymywać się od własnej przyjemności, ażeby innym nie zaszkodzić i nie dokuczyć ${ }^{41}$.

\section{Zabawki dla dziewczynek}

Dziewczynki miały bawić się przedmiotami typowymi dla zabaw dziewczęcych. Ich zabawy, na co zwrócił uwagę Łukasz Gołębiowski publikując w 1831 roku "Gry i zabawy różnych stanów", były inne od chłopięcych uciech. „Gry dziewczątek mniej szumne (...), więcej w nich spokojności, dziewczęcego wdzięku, lubej układności i chęci podobania się" ${ }^{42}$.

${ }^{41}$ Bębenek Michasia, „Dodatek do 1-go numeru Wieczorów Rodzinnych” 1899, s. 1-2.

${ }^{42}$ Ł. Gołębiowski, Gry i zabawy różnych stanów, Warszawa 1931, s. 26. 
Wśród najpopularniejszych świątecznych zabawek dziewczęcych oczywiście królowała lalka, która była wymarzoną zabawką, stając się często tytułową bohaterką bajeczek, obrazków i wierszy. Zarówno w tekstach poetyckich, jak i powiastkach znajdują się opisy zabaw lalką. Najczęściej, jak na przykład w wierszu „Lalka”, podmiot liryczny (dziewczynka) traktuje tytułową postać jak własne dziecko, będzie się nim zajmować, uszyje jej strój. Nawet ton mówiącej jest stylizowany na dorosły, co nobilituje zabawę lalką do bardzo istotnej czynności dziecięcej rzeczywistości.

Laleczko moja mała,

Dziecko moje kochane,

Ciąglem sobie myślała,

Czy cię aby dostanę?

No, i jesteś nareszcie!

$\mathrm{O} \mathrm{tu}, \mathrm{tu}$, przy choince...

Chodźcie, zobaczcie, spieszcie, -

Śpi w białej koszulince.

Dostanę skrawek płótna,

Uszyję jej sukienkę.

Nie będę zła i smutna,

Choć wezmę igłę w rękę!

Trudno! Jak się ma dzieci,

To nie można próżnować.

Strasznie prędko czas leci:

A chowaj je, a prowadź,

A szyj, a pierz, a gotuj,

A ucz, żeby zmądrzały...

Dajcie mi święty spokój, -

Cały dzień na to miały!

Niema chwili na psoty!

Jak ja się z tem obrobię?

Toż to będą kłopoty,

Nim wyrośniemy obie! ${ }^{43}$

Dydaktyzm tego wiersza jest tak dosłowny, że małej adresatce nie pozostaje wiele do dodania, jak tylko wziąć swoją lalkę i poważnie bawić się $\mathrm{z}$ nią $\mathrm{w}$ dom.

Lalkę Różę oraz pokoik dla niej otrzymała Wandzia, bohaterka „Pamiętnika lalki przez Walentynę z Trojanowskich Horoszkiewiczową". Ów pokoik

to był prześliczny pokoik. Miał cztery ściany, drzwi zamykane, szklane okna ustrojone wazonikami. I kanapę i stoliki i krzesła, biurko, szafę komodę, łóżko z pawilonem usłane do spania, a na łóżku koszulka nocna, kaftanik z falbaną i czepeczek ${ }^{44}$.

${ }^{43}$ Gwiazdka polskiego dziecka, Warszawa 1924, s. 23.

${ }^{44}$ Pamiętnik lalki przez Walentynę $z$ Trojanowskich Horoszkiewiczowa, s. 9. 
Nadawał się więc wyśmienicie do zabawy w dom, tym bardziej że zgodnie z ówczesną produkcją zabawek, mebelki w pokoiku lalczynym wzorowane były na wyglądzie prawdziwych pomieszczeń. Również Izabelka, siostra Bronka, ciesząc się z prezentów, z radością zawołała:

$\mathrm{O}$, ja teraz będę bardzo pracowita, mama zobaczy! Wszakże w tym pudełku jest naparstek srebrny, i nożyczki i igielnik śliczny z aniołkami i lusterko. Ach, mamo, mamo, co to za śliczna lalka z kapelusikiem na głowie i wachlarzem w ręku! ${ }^{45}$

W powiastce zatytułowanej „Lalka, podarunek młodym panienkom” czytelnicy poznają historię Wandzi, która na Nowy Rok otrzymała od mamy wiele różnych zabawek, $\mathrm{w}$ tym właśnie wymarzoną lalkę.

Wandzia odebrała także cacka dziecinne i tak nimi była zachwycona (...) Kiedy wszedłszy do swego pokoiku, ujrzała na swem łóżeczku maleńką, leżącą, mało od siebie mniejszą dziewczyneczkę, ale wysmuklejszej kibici i prześlicznie ubraną. Jej piękna, z jasnemi włoskami główeczka, miękko spoczywała na poduszce (...) zdawała się być uśpioną (...) Trudno opisać uniesienie i radość szczęśliwej dziewczynki. Brała ją na ręce, skakała, śpiewała, i mówiła do siebie:

O mój Boże! o mój Boże!

Co za szczęście! cóż być może

Milszego od mojej laleczki!

Co za śliczne sukieneczki!

Przy niej będę czas mój trawić

Dzielić noc, ciągle z nią się bawić,

Jak szczuplutka i zgrabniutka!

Co za buzię ma przyjemną!

Nie płacz, moja ty milutka.

Tu szczęśliwa będziesz ze mną

My się z sobą pokochamy,

Bo ja dotąd nic milszego,

Nic nad ciebie ładniejszego

Nie odebrałam od mamy"46.

Radość Wandzi po otrzymaniu wymarzonej kolędy była tak ogromna, że dziewczynka z wrażenia nie mogła spać w nocy i od dnia otrzymania laleczki, którą nazwała Lili, bawiła się nią niemal bez przerwy, zapominając o innych

${ }^{45}$ F.H. Lewastam, Obrazki z pożycia dobrej rodziny, s. 66 - 72; W powiastce „Bitwa Francuzów z Prusakami" rodzeństwo otrzymało od ukochanego wujaszka mnóstwo rozmaitych zabawek - „dwie duże lalki, dla Lucynki śliczną, ustrojoną damę z wachlarzem, a dla Anielci elegancką Krakowiankę”, [w:] M. Brühlowa, Bitwa Francuzów z Prusakami, „Dodatek do numeru 50-go Wieczorów Rodzinnych" 1889, s. 193

${ }^{46}$ Lalka. Podarunek młodym panieneczkom z obrazkami. Rozmowy, powiastki, bajeczki dla dzieci, Lwów, ok. 1850, s. 3-7. 

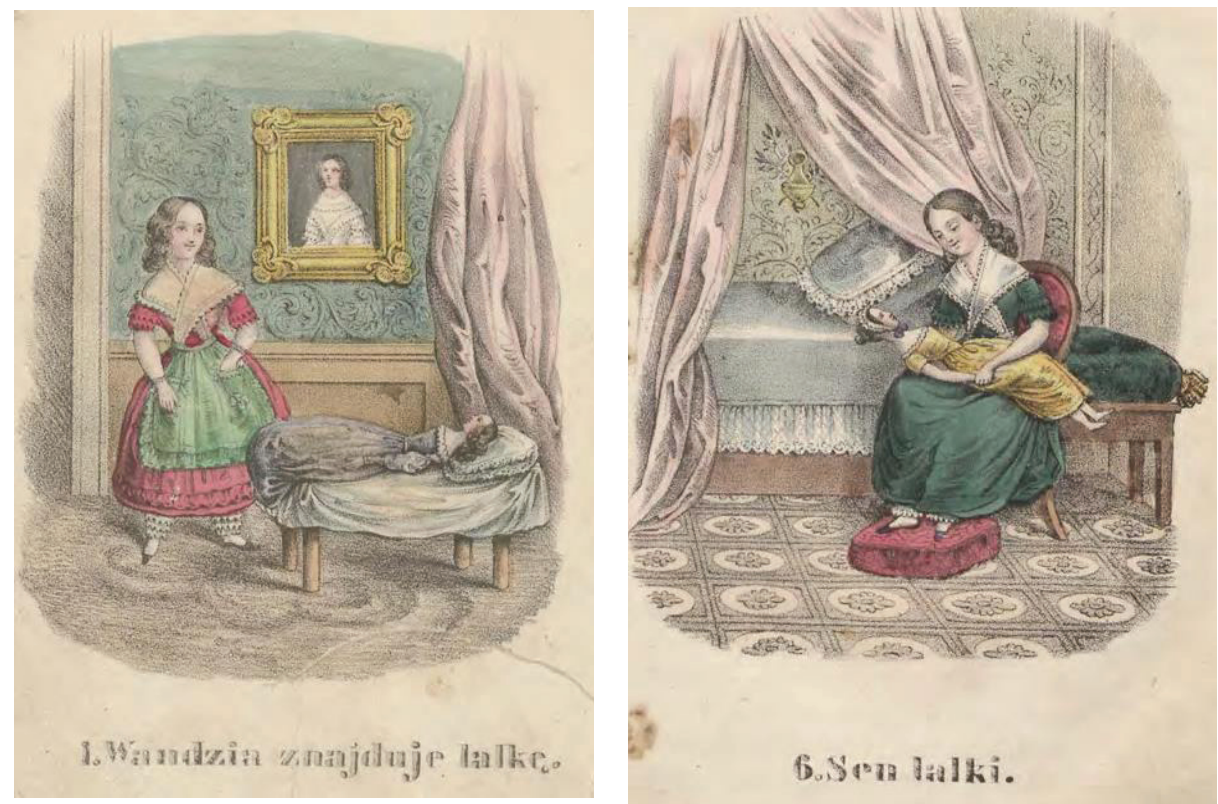

Ryc. 9. Wandzia znajduje lalkę i Wandzia usypia Lili

(Źródło: Sen lalki, [w:] Lalka. Podarunek młodym panieneczkom z obrazkami.

Rozmowy, powiastki, bajeczki dla dzieci, Lwów, ok. 1850, s. 2, 43)

zabawkach. Cała powiastka poświęcona została opisowi zabawy Wandzi z laleczką - jej usypaniu, ubieraniu, szyciu dla niej sukienek, nauce chodzenia, karmieniu, urządzaniu przyjęć, tańców.

Lalka w ręku dziewczynki spełniała wszystkie swoje funkcje: ludyczną (zabawową), obrzędową, socjalizującą, wychowawczą i edukacyjną. W tekstach intencjonalnie kierowanych do dzieci trzy ostatnie zadania stają się priorytetowe. Lalka, zabawa w dom miały wykształcić postawę dziewczynki zgodną z oczekiwaniami społecznymi - panienka miała przygotowywać się do roli dobrej żony, matki i gospodyni.

\section{Dzielenie się zabawkami}

W czasopismach dla dzieci w okresie przedświątecznym publikowano historyjki i powiastki mające na celu rozbudzać w najmłodszych wrażliwość na biedę i krzywdę innych, szczególnie rówieśników z niższych warstw społecznych. Pojawiały się więc treści, w których popularyzowano udział w zbiórkach dla ubogich i potrzebujących (redakcje niektórych pisemek prowadziły zbiórki pieniędzy dla potrzebujących, publikując na swoich łamach nazwi- 
ska darczyńców ${ }^{47}$ lub pośredniczyły w gromadzeniu darów dla potrzebują$\left(\mathrm{cych}^{48}\right)$, zalecając, aby mali czytelnicy także się w nie włączali. Mogli oni to robić, oddając swoje nieużywane już zabawki tym, którzy nigdy ich nie mieli. Gwiazdka i tak miała przynieść nowe podarki, a zabawki, z których dziecko już wyrosło, bądź którymi już się nie bawiło, mogły posłużyć i sprawić świąteczną radość innym, biednym dzieciom.

Obok oddawania starych zabawek można było także własnoręcznie, z pomocą dorosłych, przygotować różne zabawki dla potrzebujących dzieci. Na przykład, w powiastce "Choinka panny Katarzyny" Helenka wraz z Anulką pod kierunkiem ciotki Katarzyny przygotowywały lalki dla dziewczynek folwarcznych. "Ciocia wyjmuje z szafy całe tuziny lalek najprostszej budowy, w stroju zaniedbanym, a raczej bez żadnego stroju. Ale my tu urządzimy magazyn mód i przebierzemy je wspaniale" 49 . Panienki wykorzystywały zbierane cały rok skrawki tkanin, materiałów, koralików, włóczek i wyczarowywały z nich barwne stroje dla laleczek na wzór Krakowianek, Kujawianek, Ukrainek, którym starannie upinały spódnice i gorsety. Po wieczerzy wigilijnej wiejskie dzieci śpiewając kolędę odwiedzały dwór i z radością odbierały przygotowane dla nich podarki.

${ }^{47}$ "A ileż to dzieci biednych w tym dniu nie będzie miało Gwiazdki! Ileż to w dniu tym radości i wesela głodno i chłodno i ze załzawionym okiem modlić się będzie do Pana Jezusa, żeby się nad nimi zmiłował i zesłał im także gwiazdkę z nieba na ukojenie ich nędzy. Dziateczki, dla tych biednych dzieci zbieram ja składkę, chcę ja tym sierotkom bez ojca i matki także Gwiazdkę sprawić. Otwórzcie tedy skarbonki wasze i prześlijcie mi kilka groszy dla tych biednych, co boso prawie i nago, dzwoniąc od zimna zębami zmiłowania boskiego wyglądają”, w: Gwiazdka, „Nasza Gazetka: przyjaciel, nauczyciel i przewodnik. Dodatek do Nadgoplanina" 1888, nr 11, s. 43.

${ }^{48}$ Uroczyste Święto Narodzenia Jezusa Chrystusa obok wzniosłej idei religijnej, upowszechniło zwyczaj obdarzania się w rodzinnem gronie upominkami, z czego przeważnie korzysta dziatwa. Nie wszystkim jednak zarówno sprzyja szczęście, ileż to bowiem jest dzieci biednych, chorych, opuszczonych. W ich to imieniu odwołujemy się do tych dziatek szczęśliwych z prośbą, ażeby rozbudziły w swoich serduszkach poczucie litości dla biednych i przyszły z pomocą i zadowoleniem swych rodziców lub opiekunów z ofiarą w naturze, składając zużyte przedmioty jak: zabawki, ubranie, bielizny na użytek dziatek, wychodzących ze Szpitala (...) Redakcya Wieczorów również chętnie pośredniczyć może w przyjmowaniu tych ofiar, w: Od warszawskiego szpitalika dla dzieci, „Wieczory Rodzinne. Tygodnik Ilustrowany dla Dzieci i Młodzieży” 1899, nr 49, s. 392; „Pomyślcie też młodzi czytelnicy o biednych, chorych dziatkach, które tak wesołe dla was dni świąteczne przepędzać będą w szpitalu. Gdy każde z was dostanie nowe zabawki, niechże przynajmniej którą z dawniejszych ofiaruje dla tych biedaków, aby im jakąkolwiek ulge przynieść w cierpieniu i osamotnieniu”, w: „Wieczory Rodzinne. Czasopismo Tygodniowe Ilustrowane dla Dzieci" 1880, nr 52, s. 769; zob. też: Ofiara Elżuni, przez Paulinę Kraków, „Wieczory Rodzinne. Czasopismo Tygodniowe Ilustrowane dla Dzieci” 1880, nr 1, s. 6; Skarbonka Jadwini, „Dodatek do numeru 1 Wieczorów Rodzinnych” 1888, s. 2-3.

${ }^{49}$ Choinka Katarzyny. Obrazek z życia wiejskiego, „Wieczory Rodzinne. Czasopismo Tygodniowe Ilustrowane dla Dzieci" 1882, nr 53, s. 833. 
Dziewczątka nie mogły się nacieszyć cudnymi lalkami, a każdej panna Katarzyna z pomocą obu panienek tłumaczyła, jaki strój miała jej laleczka, góralki, Krakowianki czy Ukrainki i opowiadała gdzie mieszka lud, co się tak ubiera ${ }^{50}$.

Przykład powiastki mającej uwrażliwić dzieci na biedę i potrzeby innych stanowiła historyjka o Czesi, która będąc córką skromnej stróżki Janowej, mieszkała w kamienicy razem z zamożnymi dziećmi, którym szczerze zazdrościła dobrobytu. W mieszkaniu sąsiadów, na pierwszym piętrze, Wigilia i Gwiazdka obchodzona była wystawnie, z mnóstwem prezentów, łakoci i ogromną, roziskrzoną choinką.

Stasia i Zygmuś, wszedłszy do salonu, stanęli zdumieni pięknością choinki. Był to świerk aż do sufitu, strojnie przybrany, pod choinką leżały książki, lalka, fuzyjka, koń na biegunach, ciepła mufka i kołnierze ${ }^{51}$.

Mieszkająca po sąsiedzku Czesia w dzień Wigilii przyglądała się przez okno radości rówieśników i marzyła, żeby kiedykolwiek otrzymać na Gwiazdkę taką lalkę, jak Stasia.

Długo nie mogła usnąć i ciągle myślała, dlaczego na świecie tyle ludzi smutnych (...) dlaczego jedne dzieci, jak Stasia i Zygmuś, opływają w dostatki, a innym Gwiazdka tak mało przynosi. Pytania tego nie rozwiązała mała dziewczynka, ale myślała też, że gdyby Bóg dał jej być bogatą, dzieliłaby się z innymi ${ }^{52}$.

W ciągu roku Czesia poważnie zachorowała, ale kiedy Stasia i Zygmuś dowiedzieli się o jej chorobie, poprosili mamę, aby dziewczynka mogła ich odwiedzać, kiedy poczuje się lepiej. Czesia wyzdrowiała, a dzieci zaprzyjaźniły się i kolejną Gwiazdkę spędzały wspólnie, dzieląc się radością, zabawkami i łakociami ${ }^{53}$.

50 Tamże, s. 835.

51 I. Rożen, Czesia, „Moje Pisemko” 1903, nr 13, s. 217, nr 12, s. 202-204.

52 Tamże, s. 218.

${ }^{53} \mathrm{~W}$ innej powiastce znajdujemy scenę, kiedy ubogie dzieci z poddasza zostały zaproszone przez rodzinę Adasia i Zosi w wieczór wigilijny na oglądanie choinki. „Z początku biedne dzieci nie chciały wierzyć swojemu szczęściu. Z szeroko otwartymi oczkami i rączkami złożonymi jak do pacierza stały nieme przed choinką. Nie śmiały się zbliżyć ani dotknąć niczego. Gdy jednak mama Adasia i Zosi powtórzyła im kilkukrotnie „wybierzcie sobie, co wam się najbardziej podoba”, wtedy Staszek odważniejszy, sięgnął ręka po konika i trąbkę, a Kasia prawie nieprzytomna z radości klęknęła przed ogromną lalką, i zaczęła ją całować, jak żywe jakie stworzenie. Pomimo zachęty ze strony Zosi, nic więcej już wziąć nie chciała. Mam lalkę, mam lalkę - powtarzała bez końca. Z kieszeniami pełnymi pierników, jabłek i cukierków powróciły dzieci na poddasze (...). Kasia pożyczyła potem lalki do zabawy Staszkowi, a wzięła od niego konika, zabawiwszy się zaś wzięła lalkę do łóżeczka, i usnęła przyciskając córeczkę do serca", w: Niezapominajki, "Dodatek do Numeru 52-go Wieczorów Rodzinnych” 1891, s. 207-208. Podobne historyjki o dzieleniu się z ubogimi dziećmi i obdarowywaniu ich podarkami zob. np.: M. Lipska, Marzenie Walka, "Moje Pisemko” 1903, 12, s. 197-201, nr 13, s. 221-223; W Wigilię. Nie 
Przywołane sceny wyraźnie opisują ogromną radość, jaką odczuwały ubogie dzieci otrzymując zabawki, których rodzice nie byli w stanie im podarować. Emocje bohaterów powiastki miały z pewnością oddziaływać również na emocje czytelników, zachęcając ich do sprawiania radości innym, potrzebującym, szczególnie w okresie świątecznym ${ }^{54}$.

Powiastki, nowelki, czy obrazki literackie publikowane w okresie przedświątecznym miały przede wszystkim wydźwięk moralizatorski, zaś jedną z wpajanych najmłodszym postaw społecznych, z wykorzystaniem literatury, była umiejętność dzielenia się z innymi, szczególnie potrzebującymi. Przykładem takiej powiastki może być historia Marcinka, którego matka po śmierci ojca była zmuszona oddać na wychowanie do zamożnej, bezdzietnej ciotki, zaś sama pozostać $\mathrm{w}$ skromnej izbie $\mathrm{z}$ dwoma siostrami. W dniu Wigilii Bożego Narodzenia Marcinek, który był dobrym i posłusznym dzieckiem, otrzymał od ciotki mnóstwo prezentów pod choinkę.

Marcinek zobaczył na środku pokoju stojące zielone drzewko, ubrane w złocone jabłka i orzechy, pierniki, cukierki, figi, i oświecone mnóstwem kolorowych świeczek; pod drzewkiem dopiero poustawiane były zabawki, koniki, wózki, zwierzęta, gospodarstwo, nawet lalki i kuchenka ${ }^{55}$.

Chłopiec zamiast rzucić się w wir zabawy, poprosił ciocię o możliwość oddania części zabawek ubogim siostrom. Ciocia nie tylko się zgodziła, ale zrobiła wychowańcowi niespodziankę, zapraszając siostry i mamę chłopca na wspólną kolację wigilijną.

Teraz dopiero szczęśliwy Marcinek, ucałowawszy ręce ciotki, począł dzielić swoją kolendę, a kiedy już wszystkie porozstawiał zabawki, przeznaczając je to dla jednej, to dla drugiej siostry, i sobie tylko konika i biczyk zostawił, otworzyły się drzwi do sali, i dobre dziecię ujrzało matkę i siostry, które zaproszone przez ciotkę, przyjechały do niej na święta Bożego Narodzenia. Nie potrzeba wam pewno powiadać, że wszystkim doskonale smakowała wieczerza, i że Marcinkowi święta zeszły wesoło, bo kto w szczęściu o innych pamięta, temu Bóg nie tylko w pracy, lecz i w zabawie błogosławi ${ }^{56}$.

zapomnimy o nim, „Przyjaciel Dzieci” 1902, nr 52, s. 817-818; E.G., Drzewko wigiliowe, „Wieczory Rodzinne. Czasopismo Tygodniowe Ilustrowane dla Dzieci" 1883, nr 51, s. 805-808; Niespodziewana Wilia przez Bronisławe Kuczyńska, "Wieczory Rodzinne Tygodnik Ilustrowany dla Dzieci” 1887, nr 52, s. 412-416; A.L.S., Kłopot Jadzi, „Wieczory Rodzinne Tygodnik Ilustrowany dla Młodzieży i Dzieci" 1903, nr 50, s. 197.

${ }^{54}$ Zob. też np.: To dla dzieciątka Jezus, "Dodatek do numeru 52-go Wieczorów Rodzinnych" 1899, s. 205-206 (Historyjka opowiada o Zosi, oddającej swoje zabawki rodzinie w potrzebie - dziewczynka oddała dla dzieci blaszaną kuchenkę, wózek zaprzężony w konika, pasterza z krówką i swoją najpiękniejszą lalkę. „O! Ileż tam było wykrzyknień, ile łez radości! Miłość i dobroczynność oświeciły jakby jasnym światłem chatę ubogich ludzi”, w: tamże, s. 206).

${ }_{55}$ Kolenda, [w:] P. Krakowowa, Niespodzianka. Zbiór powiastek, Warszawa 1890, s. 35.

${ }^{56}$ Tamże. 
Tekst ten jest dowodem nie tylko na moralizatorstwo i nachalny dydaktyzm (szczególnie pointa) dominujące $\mathrm{w}$ tekstach adresowanych do dzieci, ale przede wszystkim stanowi świadectwo różnorodności zabawek otrzymywanych podczas świąt.

Inna powiastka, której bohaterką jest piękna porcelanowa lalka przywieziona z Niemiec do Warszawy, także ukazuje fakt obdarowywania ubogich dzieci upominkami z okazji Bożego Narodzenia. Lalka została zakupiona przez kobietę, będącą opiekunką sierot w Warszawskim Towarzystwie Dobroczynności. Kupowała ona lalki, odpowiednio je stroiła w bogate sukienki i sprzedawała zamożnym rodzinom na specjalnym kiermaszu, z którego dochód przeznaczony był na świąteczną pomoc dla potrzebujących dzieci ${ }^{57}$. Lalka - narratorka powiastki opisuje ze szczegółami inne najróżniejsze lalki, które można było nabyć na kiermaszu. Były one piękne, wyglądały jak księżniczki, w ubraniach balowych, ale też w innych toaletach - podróżnych, spacerowych, wizytowych; lalki chłopcy, w ludowych strojach (Mazurzy, Krakowiacy), w ubraniach żołnierskich, zakonnych, żydowskich. Wśród nich mniejsze laleczki, zarówno dziewczynki jak i chłopcy, tworzące grupę dzieci z ochronki, usadzone na ławeczkach oraz wiele innych.

\section{Zakończenie}

Literatura dziecięca stanowi typ literatury - „zwierciadła”, w którym odbijały się realia epoki, w jakiej powstawały. Powiastki, historyjki, wierszyki, obrazki, czy bajeczki dla najmłodszych, choć opowiadały fikcyjne historie, często oddawały rzeczywiste problemy bądź sytuacje z dziecięcego świata. Ponieważ dzieci większość czasu spędzały na zabawie, której zwykle towarzyszyły zabawki, nie brakuje zatem w utworach dla dzieci ich opisów. Zabawki nie tylko pojawiały się w powiastkach czy wierszykach jako rekwizyty zabaw, często bowiem stawały się one ich bohaterami, a nawet bywały personifikowane, pełniły rolę narratorów i przedstawiły historię ze swojej, ,zzabawkowej" perspektywy, czego przykładem mogą być utwory Jadwigi Horoszkiewiczowej. W wielu powiastkach, szczególnie publikowanych w okresie przedświątecznym, pojawiają się sceny świąteczne z Wigilią, kolędą, choinką, w których zabawki stanowią nieodłączny element treści i fabuły. Dowiadujemy się z nich, o jakich zabawkach marzyły dzieci, jakimi bawiły się w danym dziesięcioleciu, jak wykorzystywały je podczas zabaw.

Należy podkreślić, że zabawki i zabawy dziecięce występujące w tekstach intencjonalnie kierowanych do młodego czytelnika, były najczęściej

${ }^{57}$ Pamiętnik lalki przez Walentyne z Trojanowskich Horoszkiewiczowa, Warszawa - Kraków Lwów 1907, s. 3-4. 
wyrażane expressis verbis przez bohaterów dziecięcych, którzy wzajemnie przy różnych okazjach pouczają się przede wszystkim w sprawach związanych ze współżyciem $\mathrm{w}$ grupie rówieśniczej, ale także $\mathrm{w}$ różnych kwestiach związanych z normami życia zbiorowego i indywidualnego ${ }^{58}$.

I temu celowi przysłużyła się powiastka, często krytykowana już w latach 80. XIX wieku, między innymi przez Piotra Chmielowskiego. Zarzucano jej przede wszystkim tendencje moralizatorskie, które zepchnęły na dalszy plan wartości estetyczne i ludyczne ${ }^{59}$. Zjawisko to jest również widoczne w odniesieniu do zabawek dziecięcych - w prezentowanych źródłach na plan pierwszy wysuwa się ich moralizatorstwo, wręcz życzeniowość w ich stosowaniu, dzieleniu się nimi, natomiast funkcja ludyczna, o roli której w ówczesnym czasie pisali pedagodzy i psychologowie ${ }^{60}$, jest marginalizowana. Literatura dla dzieci propagowała zabawki adekwatne do płci dziecka. Jakkolwiek na łamach prasy dla dorosłych toczyły się dyskusje nad rolą zabawki, choć dawały się słyszeć postępowe głosy, mówiące o „równości” wobec wyboru zabawki ${ }^{61}$, to $\mathrm{w}$ tekstach adresowanych umyślnie do dziecka zabawki miały przygotowywać do życia zgodnie z oczekiwaniami społecznymi. Dziewczynki miały bawić się lalką, a chłopcy wojskowymi zabawkami - konikami, fuzjami, szablami, bębenkami i tym podobnymi. Zapewne wynikało to nie tylko z potrzeby naśladowania rzeczywistości w zabawie, ale również z sytuacji społeczno-politycznej oraz wychowania patriotycznego.

Podsumowując, w tekstach adresowanych do dzieci zabawka - najważniejszy towarzysz dzieciństwa - była przedstawiana bardzo często, szczególnie przy okazji zbliżających się świąt Bożego Narodzenia. Autorzy tych tekstów odwoływali się do dziecięcych marzeń o upragnionym prezencie, kreowali uroczysty i podniosły czas świąt, przedstawiali warunki otrzymania zabawki od Gwiazdora czy Świętego Mikołaja i wreszcie - pokazywali radość, emocje dziecięce z otrzymanych podarków. Co cenne z naszego punktu widzenia, w utworach tych można znaleźć opisy zabaw dziecięcych, co prawda na ogół przedstawionych $\mathrm{w}$ formie moralizowania i życzeniowości, jednak będących świadectwem „prawdziwej” dziecięcej zabawy, opartej z jednej

${ }^{58}$ G. Leszczyński, Kulturowy obraz dziecka i dzieciństwa w literaturze drugiej połowy XIX i w XX wieku, s. 138.

59 Por. R. Waksmund, Od literatury dla dzieci do literatury dziecięcej (tematy-gatunki-konteksty), Wrocław 2001, s. 392.

${ }^{60}$ Por. B. Trentowski, Chowanna, czyli system pedagogiki narodowej, jako umiejętności wychowania, nauki i oświaty, stowem wykształcenia naszej młodzieży, t. 1, Poznań 1845; H. Wernic, Wychowanie dziecka: włącznie do lat 6-ciu, Warszawa 1902; Józefa Jaxa-Bąkowska (Szczęsna), Zabawki dla dzieci, „Bluszcz” 1899, nr 50.

${ }^{61}$ Por. podrozdziały Idealna zabawka i Powinności rodziców względem zabawek, [w:] D. Żołądź-Strzelczyk, I. Gomułka, K. Kabacińska-Łuczak, M. Nawrot-Borowska, Dzieje zabawek dziecięcych na ziemiach polskich do początku XX wieku, s. 80-104. 
strony na naśladownictwie, z drugiej - na indywidualnej wyobraźni dziecka. Tej drugiej, niestety, w tekstach omawianego okresu jest niewiele, gdyż „dusza dziecka" powoli wpływała na zmiany dokonujące się w tematyce i formie tekstów do nich adresowanych.

\section{BIBLIOGRAFIA}

\section{Źródła}

A.L.S., Kłopot Jadzi, „Wieczory Rodzinne Tygodnik Ilustrowany dla Młodzieży i Dzieci” 1903, nr 50.

Bębenek Michasia, „Dodatek do 1-go numeru Wieczorów Rodzinnych” 1899.

Biart L., Pogadanki braci z siostrami, spisane ku zabawie młodych czytelników, przełożył J. Chęciński, Warszawa 1875.

Boże drzewko, „Dzwonek. Gazetka dla dzieci. Bezpłatny dodatek dwutygodniowy do Katolika" 1910, nr 26.

Brühlowa M., Bitwa Francuzów z Prusakami, „Dodatek do numeru 50-go Wieczorów Rodzinnych" 1889.

Choinka Katarzyny. Obrazek z życia wiejskiego, „Wieczory Rodzinne. Czasopismo Tygodniowe Ilustrowane dla Dzieci” 1882, nr 53.

Dary gwiazdki, „Wieczory Rodzinne” 1901, nr 51.

Dzień Świętego Mikołaja, „Światło” 1892, nr 24.

E.G., Drzewko wigiliowe, „Wieczory Rodzinne. Czasopismo Tygodniowe Ilustrowane dla Dzieci" 1883, nr 51.

E.J., Zabawki dziecinne, „Kłosy” 1885, nr 1068, nr 395.

Gołębiowski Ł., Gry i zabawy różnych stanów, Warszawa 1931.

Gwiazdka polskiego dziecka, Warszawa 1924.

Gwiazdka Przewodniczka, „Wieczory Rodzinne. Tygodnik Ilustrowany dla Dzieci” 1888, nr 51.

Gwiazdka, „Nasza Gazetka: przyjaciel, nauczyciel i przewodnik. Dodatek do Nadgoplanina" 1888, nr 11.

Gwiazdor, „Dzwonek. Gazetka dla dzieci. Bezpłatny dodatek dwutygodniowy do Katolika" 1911, nr 26.

Józefa Jaxa-Bąkowska (Szczęsna), Zabawki dla dzieci, „Bluszcz” 1899, nr 50.

Kolenda, [w:] P. Krakowowa, Niespodzianka. Zbiór powiastek, Warszawa 1890.

Kolenda, „Wieczory Rodzinne. Tygodnik Ilustrowany dla Dzieci” 1885, nr 52.

Krajewski M.D., Gry nauk dla dzieci stużące do ułatwienia ich edukacji, przez które łatwo nauczyć się moga poznawania liter, sylabizowania, czytania w polskim i francuskim języku, formowania charakteru pisania, języków ze zwyczaju, historii, geografii i początków arytmetyki, Kraków 1777.

Lalka. Podarunek młodym panieneczkom z obrazkami. Rozmowy, powiastki, bajeczki dla dzieci, Lwów, ok. 1850.

Lewestam F.H., Obrazki z pożycia dobrej rodziny, Warszawa 1844.

Lipska M., Marzenie Waldka, „Moje Pisemko” 1903, nr 12, nr 13.

Narzędzia, [w:] B. Ostrowska, Gwiazdka polskiego dziecka, Warszawa 1924.

Niespodziewana Wilia przez Bronistawę Kuczyńska, „Wieczory Rodzinne Tygodnik Ilustrowany dla Dzieci" 1887, nr 52. 
Niezapominajki, „Dodatek do Numeru 51-go Wieczorów Rodzinnych” 1891.

Ofiara Elżuni, przez Paulinę Kraków, „Wieczory Rodzinne. Czasopismo Tygodniowe Ilustrowane dla Dzieci" 1880, nr 1.

Pamiętnik lalki przez Walentynę z Trojanowskich Horoszkiewiczowa, Warszawa - Kraków Lwów 1907.

Piękny podarunek, „Dzwonek. Gazetka dla dzieci. Bezpłatny dodatek dwutygodniowy do Katolika" 1909, nr 26.

Piosenka o choince, [w:] Upominek z prac Jachowicza. Bajki, nauczki, opisy, powiastki i różne wierszyki z 40 obrazkami, wyd. III, Poznań 1902.

Pod choinka, „Wieczory Rodzinne. Tygodnik Ilustrowany dla Młodzieży i Dzieci” 1902, nr 51.

Przewodnik w zdrowym pielęgnowaniu dzieci od przyjścia na świat aż do dojrzenia, skreślony przez przyjaciela dzieci (lekarza), Lwów 1869.

Rogożewski R., Jakie zabawki kupować dzieciom, „Dziecko” 1913, nr 9.

Rożen I., Czesia, „Moje Pisemko” 1903, nr 12, 13.

Rykaczewski E., Stownik języka polskiego podtug Lindego i innych nowszych źródet, t. II, Berlin - Poznań 1866.

Seidlerowa Z., O zabawkach, „Bluszcz” 1904, nr 50.

Skarbonka Jadwini, „Dodatek do numeru 1 Wieczorów Rodzinnych” 1888.

Stownik języka polskiego przez M.S.B. Linde, t. VI, U-Z, Warszawa 1814.

Stownik języka polskiego, obejmujący oprócz zbioru właściwie polskich, znaczna liczbe wyrazów z obcych języków (...) do podręcznego użytku, cz. 2, P-Ż, Wilno 1861.

Stownik języka polskiego, red. J. Karłowicz, A. Kryński, W. Niedźwiedzki, Warszawa 1927.

Świateczne prezenty, „Moje Pisemko” 1908, nr 13.

Święty Mikołaj, „Dzwonek. Gazetka dla dzieci. Bezpłatny dodatek dwutygodniowy do Katolika" 1905, nr 25.

Święty Mikołaj, „Moje Pisemko” 1903, nr 10.

To dla dzieciątka Jezus, „Dodatek do numeru 52-go Wieczorów Rodzinnych” 1899.

Trentowski B., Chowanna, czyli system pedagogiki narodowej, jako umiejętności wychowania, nauki i oświaty, słowem wykształcenia naszej młodzieży, t. 1, Poznań 1845.

WWigilię. Nie zapomnimy o nim, „Przyjaciel Dzieci” 1902, nr 52.

Wernic H., Wychowanie dziecka: włącznie do lat 6-ciu, Warszawa 1902.

Włodkówna B., Czy Baśka dobrze zrobiła? „Światek Dziecięcy” 1910, nr 5.

Złoty wiek dziecięcy. Wierszyki i obrazki dla matych dziatek, Kraków 1890.

\section{Opracowania}

Adamczykowa Z., Literatura dla dzieci. Funkcje, kategorie, gatunki, Warszawa 2001.

Bujak J., Pilichowska B., Zabawki, potrzeby badawcze, problemy teoretyczne, propozycje muzeologiczne, Studia i Materiały 1986, 1.

Bujak J., Zabawki w Europie. Zarys dziejów - rozwój zainteresowań, Kraków 1988.

Dawne zabawy dziecięce, red. D. Żołądź-Strzelczyk, K. Kabacińska, Kielce - Warszawa 2008.

Dawne i wspótczesne zabawki dziecięce, red. D. Żołądź-Strzelczyk, K. Kabacińska, Poznań 2010.

Encyklopedia wiedzy o prasie, red. J. Maślanka, Wrocław - Warszawa - Kraków - Gdańsk 1976.

Grabowski S., Na przyszły pożytek. Z dziejów polskiej prasy dla dzieci 1824-1939, Pułtusk 2001.

Kabacińska K., Zabawy i zabawki dziecięce w osiemnastowiecznej Polsce, Poznań 2007. 
Kabacińska K., Zabawy i zabawki dziecięce w świetle polskiej nowelistyki pozytywistycznej, Zabawy i Zabawki, 2008, 1-4.

Kabacińska K., Od grzechotki do.... - stów kilka o zabawkach dziecięcych, Studia Edukacyjne, 2010, 11.

Kabacińska-Łuczak K., Nawrot-Borowska M., Dziecięce zabawki świąteczne w świetle wybranych źródet ikonograficznych z II połowy XIX i początku XX wieku, Studia Edukacyjne $2017,46$.

Kuliczkowska K., Literatura dla dzieci i młodzieży w latach 1864-1918, Warszawa 1975.

Leszczyński G., Kulturowy obraz dziecka $i$ dzieciństwa w literaturze drugiej połowy XIX $i$ w XX wieku, Warszawa 2006.

Nawrot-Borowska M., Zabawy $i$ zabawki dziecięce w drugiej połowie XIX i na poczatku XX wieku - wybrane problemy z wykorzystaniem grafik z epoki, Biuletyn Historii Wychowania, $2013,30$.

Nawrot-Borowska M., Obrazki z dziejów lalki, [w:] Z badań nad tradycja polskiej pedagogiki, t. 2: Księga jubileuszowa dedykowana Profesor Danucie Koźmian, red. E. Magiera, J. Król, Szczecin 2016.

Nawrot-Borowska M., Kabacińska-Łuczak K., Co podarować dziecku na Gwiazdkę? Porady pedagogiczne i oferty reklamowe dla kupujacych zabawki z II połowy XIX i poczatku XX wieku, [w:] Dom-codzienność i święto. Ceremonie i tradycje rodzinne. Studia historyczno-antropologiczne, red. B. Popiołek, M. Gadocha, A. Chłosta-Sikorska, Kraków 2018.

Okoń W., Zabawa a rzeczywistość, Warszawa 1987.

Papuzińska J., Wychowawcza rola prasy dziecięcej, Warszawa 1972.

Przecławska A., Czasopisma dziecięce i młodzieżowe, [w:] Encyklopedia pedagogiczna, red. W. Pomykało, Warszawa 1997.

Stare i nowe. Czasopisma dla dzieci i młodzieży, red. B. Olszewska, E. Łucka-Zając, Opole 2013.

Waksmund R., Od literatury dla dzieci do literatury dziecięcej (tematy-gatunki-konteksty), Wrocław 2001.

Zabawka - przedmiot ludyczny i obiekt kolekcjonerski, red. K. Kabacińska-Łuczak, D. Żołądź-Strzelczyk, Poznań 2016.

Żołądź-Strzelczyk D., "A cacek też dużo byto”. Zabawki dziecięce na ziemiach polskich w średniowieczu i epoce nowożytnej, Kwartalnik Historyczny, 2013, 1.

Żołądź-Strzelczyk D., Rola zabawek w przygotowaniu do petnienia ról społecznych kobiecych i męskich w epoce nowożytnej, [w:] Kobieta i mężczyzna jedna przestrzeń - dwa światy, red. B. Popiołek, A. Chłosta-Sikorska, M. Gadocha, Warszawa 2015.

Żołądź-Strzelczyk D., Gomułka I., Kabacińska-Łuczak K., Nawrot-Borowska M., Dzieje zabawek dziecięcych na ziemiach polskich do początku XX wieku, Wrocław 2016. 